IZA DP No. 5030

The State of Collective Bargaining and Worker Representation in Germany: The Erosion Continues

John T. Addison

Alex Bryson

Paulino Teixeira

June 2010
André Pahnke

Lutz Bellmann 


\title{
The State of Collective Bargaining and Worker Representation in Germany: The Erosion Continues
}

\author{
John T. Addison \\ University of South Carolina, \\ Queen's University School of Management and IZA
}

Alex Bryson

National Institute of Economic and Social Research and CEP

Paulino Teixeira

Faculdade de Economia/GEMF, University of Coimbra

André Pahnke

Institute for Employment Research (IAB)

Lutz Bellmann

Friedrich-Alexander-Universität Erlangen-Nürnberg, Institute for Employment Research (IAB) and IZA

\author{
Discussion Paper No. 5030 \\ June 2010
}

IZA

P.O. Box 7240

53072 Bonn

Germany

Phone: +49-228-3894-0

Fax: +49-228-3894-180

E-mail: iza@iza.org

Any opinions expressed here are those of the author(s) and not those of IZA. Research published in this series may include views on policy, but the institute itself takes no institutional policy positions.

The Institute for the Study of Labor (IZA) in Bonn is a local and virtual international research center and a place of communication between science, politics and business. IZA is an independent nonprofit organization supported by Deutsche Post Foundation. The center is associated with the University of Bonn and offers a stimulating research environment through its international network, workshops and conferences, data service, project support, research visits and doctoral program. IZA engages in (i) original and internationally competitive research in all fields of labor economics, (ii) development of policy concepts, and (iii) dissemination of research results and concepts to the interested public.

IZA Discussion Papers often represent preliminary work and are circulated to encourage discussion. Citation of such a paper should account for its provisional character. A revised version may be available directly from the author. 
IZA Discussion Paper No. 5030

June 2010

\section{ABSTRACT \\ The State of Collective Bargaining and Worker Representation in Germany: The Erosion Continues}

This paper investigates trends in collective bargaining and worker representation in Germany from 2000 to 2008. It seeks to update and widen earlier analyses pointing to a decline in collective bargaining, while providing more information on the dual system as a whole. Using data from the IAB Employment Panel and the German Employment Register, we report evidence of a systematic and continuing erosion of the dual system. Not unnaturally the decline is led by developments in western Germany. Arguably, the path of erosion will continue until rough and ready convergence is reached with eastern Germany. Expressed differently, if the process of decentralization underpinning these developments once was 'regulated' it no longer appears to be so.

JEL Classification: J50, J53

Keywords: erosion of the dual system, collective bargaining/works council coverage, eastern and western Germany, institutional transitions, permanent stayers, newly-founded firms, closing/failing firms

Corresponding author:

John T. Addison

Hugh C. Lane Professor of Economic Theory

Moore School of Business

University of South Carolina

1705 College Street

Columbia, SC 29208

USA

E-mail: ecceaddi@moore.sc.edu 
While this process of institutional erosion may take a long time, in the end, the German model of industrial relations will more and more lose its exclusivity and distinctiveness (Hassel, 1999: 503).

\section{Introduction}

Shrinking collective bargaining coverage in Germany is not new. Nor for that matter is it long standing, so much so that observers tended to equate the case of Germany with institutional resilience and path dependence. Among the first to identify quantitative changes in the twin pillars of the German dual system of industrial relations was Hassel (1999), who noted the falling proportion of employees covered by sectoral agreements and a certain weakening in works council coverage. Hassel (2002) subsequently reaffirmed her erosion-plus-decentralization thesis. A protean debate on the possibly cyclical nature of the trends pointed to by Hassel (see, for example, Klikauer, 2002) proved short lived as other observers were soon to chart decline along both these and also a number of other gradients, such as firm resignations from employers' associations and sharply declining union density (see respectively, Kohaut and Schnabel, 2003a; Silvia and Schroeder, 2007; Addison, Schnabel, and Wagner, 2003).

But the overall evidence on the coverage of the institutions of German industrial relations is now both dated and piecemeal, and there is therefore a need to provide updated and more comprehensive information on the extent of collective bargaining and works council coverage. Has the decline in sectoral bargaining continued or has it subsided (perhaps as a result of contractual innovations such as opening clauses, pacts for employment and competitiveness, and weaker forms of membership in employer associations) ${ }^{1}$ Has decentralization taken the form of a rising coverage of firm agreements on the Anglo-Saxon pattern? And does the course of representation in works councils point to a growing codetermination deficit?

We seek answers to these broad questions using data from IAB Establishment Panel, 1999-2009. Specifically, we shall chart the share of firms and employees covered by both sectoral and firm-level collective bargaining and, crucially, the default of no collective bargaining. We also chart the establishment coverage of and worker representation in works councils. In each case, we address full cross sections

of establishments as well as their key constituents. Specifically, in addition to the aggregate findings we are interested in the results for permanent stayers (i.e. 
continuing establishments observed in every single year of the sample) newly-founded establishments (or births), and closing/failing establishments (deaths).

To anticipate our findings, and as our title suggests, we conclude that the erosion in sectoral collective bargaining first observed in the 1990s is ongoing. Moreover, the decline is across the board, being observed for each of the samples identified here. That said, there are marked regional differences. The erosion is more pronounced in western Germany, and possibly represents the working out of a process of convergence. We even detect some erosion in codetermination, on which development there was no real consensus in the previous literature. Ironically, the decline in works council frequency detected here follows in the wake of changes in the enabling legislation in 2001 designed to promote works council formation (see Bellmann and Ellguth, 2006). Finally, there is no real suggestion of any material increase in firm-level collective bargaining.

Not directly examined here are the consequences of the erosion in collective bargaining. (And we will take it as read that there is no real disagreement over the forces promoting institutional change: globalization, high unemployment, unification, and structural shifts in employment patterns.) Thus, investigation of the impact of changes in the industrial relations system on, say, wage determination and wage dispersion is left to a later date. To repeat, our goal is rather to set down the facts of the case, to provide an updated and thorough description of changes in the dual system and establish the status quo ante.

\section{Some Opening Remarks on the Erosion-Decentralization Thesis}

The German system of (relatively) centralized wage bargaining is widely recognized as having displayed considerable stability until the end of the 1980s, with the second tier of the dual system allowing German industrial relations to accommodate to a trend toward decentralization in that decade (Thelen, 1991). In short, sectoral agreements continued to dominate in Germany long after their demise in other regimes because of the substantial devolved labor powers of workplace codetermination.

The erosion of the German system of industrial relations since the early 1990s has been analyzed by Hassel (1999), who identifies a decline in the coverage of plantlevel codetermination and sectoral collective bargaining, that is, across both pillars of

the dual system. Of the two, she argues that the decline in works council coverage has 
been the more profound since there are collective agreements for almost all economic sectors. $^{2}$ But on the collective bargaining front, Hassel identifies two major developments: a steady increase in the number of company agreements relative to central (i.e. sectoral) agreements, especially in west Germany where they are less common than in east Germany, and the corollary of a pronounced decrease in the membership rates of employers' confederations. Hassel argues that the decline in coverage by German industrial relations institutions as a whole has coincided with greater pressure towards decentralization in collective bargaining. She distinguishes between regulated decentralization (via opening clauses, hardship agreements, and company-specific agreements) where the parties have sought to pre-empt pressures to decentralize collective bargaining by allowing for some differentiation while avoiding delegating decision-making rights on wages to plant level and actual deviations from standard terms and conditions in some 'pacts' where management has opened up an independent or substitute collective bargaining agenda from below. But she is concerned to warn that regulated decentralization may be no less divisive and ultimately destabilizing for the system than processes of decentralization from below. In sum, Hassel contends that the German system is under challenge as a result of shrinking regulative capacity in conjunction with increasing decentralization pressures.

In updating her analysis, Hassel (2002) argues that the evidence continues to support her erosion thesis. Drawing on survey data, she notes that between 1995 and 1998 the plant coverage rate of sectoral agreements in west (east) Germany shrank from 53.4 percent (27.6 percent) 47.7 percent (25.8 percent). In terms of private sector employee coverage the corresponding values for west (east) Germany were 72.2 percent and 67.8 percent (56.2 percent and 50.5 percent). She also observes a further decline in the membership of employer associations (strictly speaking only the case of Gesamtmetall is investigated) which were becoming increasingly dominated by large employers, and a further shift away from sectoral agreements, again indexed by an increase in company agreements as a share of total agreements. She further reports a pronounced fall in union density (from 27 percent in 1980 to 18.6 percent in 1999) and a sharp increase in non-unionized works councillors (up from 26.5 percent in 1994 to 33.3 percent in 1998).

Now there is a growing literature on the changes under way in Germany's coordinated model of industrial relations (see below), but this has tended to focus 
more on the broad theme of decentralization than on presenting a comprehensive review of the facts of the case in terms of the coverage of collective bargaining and worker representation (or drawing on them in the manner of Hassel). As a practical matter, information on such representation tends to be either dated or partial. Thus, we have rather patchy data on sectoral bargaining coverage over the course of the present decade. Much of the information pertains to developments between 1995 and 2001 (Kohaut and Schnabel, 2003a, 2003b). Some more recent studies that confirm the diminishing importance of sectoral agreements identified earlier do not range beyond 2005 (e.g. Kohaut and Schnabel, 2007). Such treatments typically lack supportive data on the course of plant-level collective bargaining proper or the collective bargaining free zone and fail to identify parallel developments in worker representation through works councils. ${ }^{3}$ Exceptions are the study by Addison et al. (2009) which covers the interval 1998-2004, and upon which the present treatment builds, and the 'updates' provided by Ellguth and Kohaut $(2008,2010)$ in which close attention is paid to the holes in occupational and branch coverage. In another recent treatment, Kohaut and Ellguth (2008) also add an interesting wrinkle in distinguishing between closing, continuing, and new establishments. Our treatment will introduce the latter innovation in presenting comprehensive information on collective bargaining coverage and worker representation. $^{4}$

As noted earlier, the second and dominant strand of the German research has focused on the mechanics of the decentralization process. As we have seen, decentralization is in principle compatible with unchanged sectoral bargaining coverage under 'regulated decentralization.' Although they would certainly not contest the facts of changes in institutions and collective bargaining coverage noted earlier, perhaps the majority of observers have concluded from their examination of the collective bargaining process pace Hassel that the system is not destabilizing. Thus, it has been argued that experience supports the idea that German employers have a vested interest in maintaining the dual system (e.g. Thelen and Van Wijnbergen, 2003) and that the system admits of powerful flexibility, allowing outsourcing and other adjustments to change without precipitating conflict (e.g. Streeck, 2001), underscored by pervasive cooperation (Frege, 2003). For these observers the dual system remains intact by managing to achieve "transformation without disruption” (Streeck and Thelen, 2004: 4). 
While Hassel (1999: 502) would undoubtedly agree with this diagnosis for the category of large manufacturing firms, she would argue that the system is unstable because its glue in the form plant-level codetermination is eroding while the emergence of a growing gap between highly regulated sectors with strong industrial relations institutions and poorly regulated sectors with weak institutions inevitably compounds conflictual relations between companies of different sizes within employer groups, adding to the problem of collective action on the part of these confederations. A similar argument has more recently been advanced by Doellgast and Greer (2007) in a study of outsourcing in the German telecommunications and auto industries. The authors argue that as core employers migrate jobs to subcontractors, subsidiaries, and temporary agencies they introduce new organizational boundaries across the production chain and disrupt traditional bargaining structures. The authors further contend that as a practical matter the response by worker representatives to re-establish representation in the new sectors has failed to restore coordinated bargaining. In other words, they see the system as fragmenting, and view decentralization as increasingly uncontrolled, at least as far the two sectors they examine are concerned. ${ }^{5}$

To a very considerable degree, debate over the 'transformation without disruption' issue has proceeded more on the basis of the performance of actual collective agreements rather than upon numerical decline in the institutions of collective bargaining and worker representation. As we have seen, the main exception is Hassel partly because of the emphasis she places on the complementary relation between codetermination and collective bargaining (so that any material erosion of codetermination means that collective bargaining proper will be less able to perform its regulative tasks) and partly because the growth in poorly regulated sectors increases the problem of collective action of employers' confederations.

In the present treatment, we intend to provide chapter and verse on the course of collective bargaining and worker representation over a longer period than previously examined, distinguishing between mutually exclusive sectoral agreements and firm-level collective bargaining, charting the growth of the collective bargaining free zone, and mapping changes in works council coverage. Our goal is to inform the wider debate although decentralization within sectoral bargaining that may be no less disruptive will perforce escape identification. Our maintained hypothesis is that if we 
observe substantive long-term institutional change the German model is, as Hassel contends, more likely to be 'disorganized' and less likely to be distinctive.

\section{Data}

Our raw data source is the IAB Establishment Panel (or Betriebspanel), a stratified random sample of plants extracted from the population of all establishments with at least one employee covered by social insurance. ${ }^{6}$ From the outset, the Establishment Panel was designed to provide a continuous analysis of the labor market in Germany and as a result it has an interesting longitudinal dimension, allowing us to follow a sizeable number of establishments in successive years over a substantial period of time. Over our sample period - 2000-2008 - the share of establishments that is observed in every single year (or 'permanent stayers') approximates 20 percent. The remaining 80 percent comprise pure panel rotations together with establishment births and deaths.

Although the IAB establishment panel contains information on whether any given establishment was created before a certain date, establishments are generally not asked to provide their exact year of birth. Moreover, since the panel questionnaire is not always framed in the same way over time (and the management respondent may differ through time and/or provide inconsistent answers), exclusive reliance on Betriebspanel data involves a non-negligible possibility of error in coding the year of birth. More concretely, the actual survey procedure is to ask the establishment respondent whether or not the plant was founded prior to or after the year 1990. Only those answering that the plant was born in or after 1990 are then asked to provide the exact year of birth. The exception is those establishments that are interviewed for the first time, all of which are required to provide information on their year of birth. ${ }^{7}$

In analyzing our raw data, we pay very careful attention to this issue of births (as well as closings/deaths, described below) and the manner of their identification. To this end, we ran various checks to ensure correct enumeration of the number of births (and closings/deaths). To give a quick illustration of the problems of relying exclusively on the Betriebspanel, we found that for approximately 8 percent of all establishments over the sample period it was not possible to establish with precision whether the plant was founded before or after 1990. In addition, some 6 percent of those plants reporting that they were not born before 1990 failed to provide the same year of foundation in successive surveys. 
In the light of these limitations, it is apparent that the Betriebspanel cannot provide an exact map of the year of establishment birth. We therefore decided to follow a different route to identify newly-born establishments. This procedure involved use of the establishment register (or Betriebsdatei). Specifically, for all establishments present in the Betriebspanel that were interviewed at least once over the 2000-2008 interval (approximately 38,500 units in all), we generated $D_{t}$ year dummies equal to 1 if the establishment was present in the Betriebsdatei in year $t, 0$ otherwise (where $t=1995,1996, \ldots, 2009$ ). Note further that since (a) the Betriebsdatei contains, in any given year, all German establishments that have paid social security contributions for at least one of its employees, and (b) the Betriebspanel is drawn from the Betriebsdatei records, it follows that the two datasets share the same establishment identification code (or Betriebsnummer). This means, therefore, that at any given point in time it is possible to determine the year of birth of any establishment in the Betriebspanel, assuming that the first year of entry in the Betriebsdatei is the correct year of birth. ${ }^{8}$ Finally, we should note that since the Betriebspanel is drawn one year in advance - that is, the Betriebspanel for year $t$ is extracted from the set of all establishments included in the Betriebsdatei in year t-1 an establishment entering the former in year $t$ for the first time will only be coded as a birth if it was observed in the latter in year $t-1$ but not prior to $t-1 .^{9}$

A similar procedure is used to code establishment closings/deaths. If establishment $j$ leaves the Betriebspanel in year $t$ and it is not found in the Betriebsdatei in year $t+1$, it will be coded as a death in year $t+1$. We note parenthetically that up to the year 2009 we can also track closings/deaths occurring in the post- $t+1$ period.

(Table 1 near here)

In Table 1 we present the full set of sample categories and their definitions. The mutually exclusive or disjoint categories are such that in any given year it is possible to determine whether: (a) an establishment is in the panel for the first time; (b) it is a continuing or a newly-born establishment; (c) it is present in the panel in any of the following years; and (d) whether an establishment exit from the panel is due to pure rotation or an establishment death. In total, we have thirteen categories. These can then be aggregated to provide, in any given year, the share of births, deaths, and permanent stayers, inter al., as will be discussed in the findings section below. To our knowledge, this is the first time such a detailed decomposition has been attempted, 
and we think it is worthwhile given our intention to understand the changing patterns of collective bargaining and worker representation in Germany over a period of almost a full decade. We again note that such an exercise would be impossible without using the Betriebsdatei (i.e. in conjunction with the Betriebspanel).

To put all our thirteen categories in a unified context, consider, for the sake of the argument, the year 2000. Here Group 1 (entry/birth), for example, is made up of all establishments that are in the IAB panel survey for the first time (i.e. they were not in the 1999 panel) and were actually born in 1999 according to the business register. Group 1 is to be distinguished from Group 2 in the sense that although establishments in the latter are also in the panel for the first time, the business register tells us they were born before 1999; from Group 5 since establishments in Group 1 are observed at least once after 2000 (i.e. they are not single-year stayers in the panel); and from Group 6 (Group 7) because establishments in Group 1 do not die/close in 2001 (or later).

Group 4, comprising temporary stayers, is a residual category made up of those establishments that are observed in 2000 (and 1999) and after 2000. (It also can include establishments observed in 2000 and 2008 but not in every single year of the sample.) All single-year panel stayers populate Groups 5 through 10, while establishments exiting the panel in year 2000 (i.e. those observed in 2000 - and in 1999 - but not later) occupy groups 11 to $13 .^{10}$

Over the entire 2000-2008 period, the raw sample contains some 140,000 observations. The following filters were then applied to generate a sample of nine cross-sections: first, the selection of all industries except agriculture and the extractive industries; second, the selection of establishments employing at least 5 employees (since this is the employment threshold for works council formation); third, the excision of plants where information on sales is not provided; and, finally, the exclusion of any public corporations. To be included all establishments had also to have information on their collective agreement and works council status. These restrictions resulted in a total of approximately 75,000 observations. All our results in the findings section below are cross-section weighted, using the inverse of the selection probability. Given the nature of the weighting process, it is generally the case that an establishment is allocated different weighting factors in any two subsequent waves. 


\section{The Course of Collective Bargaining and Worker Representation, 2000-2008}

Data on the extent of collective bargaining coverage and worker representation by establishment and employment for each of the nine cross sections of data is documented in Appendix Table 1. Figures 1 and 2 present the information in more digestible form. At the most general, all-German, level we see that collective bargaining has declined. But the decline is confined to the sectoral level. Plant coverage of sectoral bargaining is down from 47.3 percent in 2000 to 35.4 percent in 2008, while there is some tiny increase in firm-level collective bargaining. The corollary is a marked growth in the proportion of uncovered establishments: plants without a collective agreement of any kind have grown from 50.1 percent to 61.9 percent of the total. For its part, the works council coverage of establishments has slowly but assuredly declined (see Figure 1). When one turns to examine collective bargaining coverage and worker representation by employment (see Figure 2) it is the case that the fall in sectoral bargaining is more muted (from 57.3 percent to 48.1 percent), while there is again a modest rise in the share of firm-level agreements. Nevertheless, the growth in absence of collective bargaining coverage of any kind is still pronounced (up from 35.9 percent in 2000 to 44.2 percent in 2008). Interestingly, the share of workers in works council firms vastly exceeds the share of works council firms - since works councils proliferate in larger establishments - but the decline in works council coverage is still nontrivial on this measure (some 3.5 percentage points).

(Figures 1 and 2 near here)

There are some marked differences in the course of collective bargaining and worker representation between the two halves of Germany. In the east, sectoral bargaining coverage by establishments is markedly lower than in the west but has declined less. In the west, equal numbers of firms had no collective bargaining as had sectoral agreements as early as 2002. If anything, firm-level bargaining is more entrenched in the east and admits of no decline (as is also true of the west). Although firms without collective bargaining of any type much more clearly dominate in the east, the growth of this sector has inevitably been much smaller in the east. On the other hand, both the incidence of and the pattern of decline in the share of plants with works councils is very similar in the two broad regions (see Figure 1). What further regional differences emerge when we turn to look at coverage by employment? Perhaps the most obvious reading of Figure 2 (vis-à-vis Figure 1) is that although the 
aggregate results are more clearly driven by the west, the absolute trends tend to be closer.

Two issues not considered earlier are the concept of orientation toward a sectoral collective agreement and the concatenation of works councils and collective bargaining. Beginning with the former, German employers often claim that though not party to a sectoral agreement they nonetheless orient themselves to one. Now orientation toward a collective agreement may in the limit amount to little more than monitoring, but by the same token it may constitute rather more than that. Clearly further investigation of this issue is required to establish the coerciveness or otherwise of such comparisons. Pending that inquiry, here we simply ask whether the fall in sectoral bargaining/rise in the collective bargaining free zone charted earlier has been accompanied by (possibly offsetting) changes in orientation. At the start of our sample period in 2000 some 25.2 percent of all establishments covering 18.7 percent of all employees claimed to orient themselves towards a collective agreement. By 2008 these proportions had risen to 28.9 percent and 22.7 percent, respectively. ${ }^{11}$ However, these increases in were eclipsed by the growth in the collective bargaining free zone, such that we observe a falling share of orienting establishments in this firmament; specifically, the share of plants claiming to orient themselves towards a collective agreement fell from 50.6 percent of establishments without a collective agreement in 2000 to 47.9 percent of such plants in 2008. It is therefore hard to resist the conclusion that erosion also attaches to the admittedly black box of orientation.

Next let us consider the joint presence of both pillars of the German system of industrial relations: collective bargaining and workplace codetermination. Although not reported in our tables, the proportion of establishments (employees) covered neither by collective agreements nor by works councils rose from 47.7 percent (29.1 percent) in 2000 to 59.6 percent (35.3 percent) in 2008. The increase was monotonic in the case of employment. Correspondingly the proportion of establishments (employees) having both industrial relations institutions was 7.9 percent (38.5 percent) in 2000, falling to 5.8 percent (32.9 percent) in 2008. More specifically, at the start of the period, 6.5 percent (32.7 percent) of establishments (employees) were covered by sectoral agreements and works councils whereas eight years later only 4.8 percent (26.6 percent) of establishments (employees) were in that position. ${ }^{12}$ This indicates a clear erosion of the dual system. And overall, while works council 
coverage by establishment and employment fell in sectors with collective bargaining, works council growth was recorded in sectors without collective bargaining.

(Figures 3 near here)

To what extent do the results formally reported thus far compound very different trends at a truly more disaggregate level? To address this issue Appendix Tables 2 through 4 examine the same body of evidence considered earlier for three different configurations of the sample: permanent stayers, newly-founded establishments, and closing establishments, respectively. Also as before this information is presented graphically (in Figures 3 through 5). Beginning with those firms that were present in each wave of the sample period - the category of permanent stayers - the coverage by establishment data summarized in Figure 3 closely resembles those reported earlier for the full sample. This is not simply for the allGerman case but also for east and west Germany as well. Thus, for Germany as a whole, sectoral bargaining coverage by establishment declined from 50.1 percent in 2000 to 40.1 percent in 2008 and the share of establishments without collective bargaining of any sort rose from 47.9 percent to 57.6 percent, somewhat less marked than in the entire cross section. Works council coverage also declined but again less markedly. We observe a broadly similar stability in firm-level collective bargaining coverage. There are no major differences at regional level.

(Figure 4 near here)

Greater differences emerge from Figure 4 when we consider coverage by employment. Thus, the gap between sectoral agreements and absence of any agreement admits of less convergence for the permanent stayer sample even if the trends in each are directionally the same. There are also some indications of an increase in works council coverage on this measure. But the main results still stand: a decline in traditional collective bargaining and growth in no agreements. That said, the decline in sectoral bargaining is much less in evidence for east Germany and there is no employment growth in the no-agreement sector. Both indicators in fact display broad stability. Firm-level agreements are somewhat more important in the east than before.

(Figure 5 near here)

If the results for permanent stayers rather closely resemble those reported for the overall sample, what of the experience of newly founded enterprises? Figure 5, which presents results for Germany as a whole (but see Appendix Table 3 for the 
regional breakdowns), indicates that the reach of sectoral agreements using either establishment or employment coverage is much lower than for the preceding groups and the importance of the no agreement category correspondingly somewhat elevated. But although the changes are more muted we can say that the directional movements in each are directionally as before for employment coverage (if not establishment coverage). Thus, the employment coverage of sectoral agreements fell from 41.8 percent to 38.4 percent while that of the collective bargaining free sector rose from 52.6 percent to 54.3 percent. (For west Germany, the trends in sectoral bargaining coverage by establishment mirror these results.). Works council employment and establishment coverage declined for both parts of Germany but increased in the case of firm-level bargaining.

(Figure 6 near here)

Finally, Figure 6 summarizes the situation for plant closings and deaths. Perhaps the first observation to be made is that the collective bargaining coverage of plants that close or die is not consistently higher than that of survivors (although more so in the case of employment coverage). By the same token the coverage of the collective bargaining free zone is sometimes higher and sometimes lower among the former group. Nor for that matter is works council employment coverage greater. Rather, the distinctive feature of plant closings/deaths resides in trends that closely match those of the full sample. Thus, their sectoral agreement coverage by establishment (employment) fell from 31.3 percent (45.4 percent) in 2000 to 23.5 percent (39.2 percent) in 2008. The corresponding increases in absence of any coverage were from 61 percent (45.8 percent) in 2000 to 74.2 percent (53.8 percent) in 2008. Pari passu with the full sample, works council coverage trended down while firm-level bargaining increased somewhat.

Similarities in disaggregations of the data are more common than the differences. Vulgo: sectoral bargaining is in retreat and there is a rise (often steep) in the collective bargaining free zone. Reflecting the latter phenomenon there is no suggestion of a sustained increase in firm-level collective bargaining. There is also no suggestion of an increase in worker representation through works councils. Indeed the evidence is to the contrary so that taken in conjunction with our other findings the implication may well be that there is also a growing codetermination free zone. One tantalizing result is that closing establishments show no tendency to be more subject to sectoral collective bargaining than their surviving counterparts. 
In Tables 2 through 4 we present evidence on establishment transitions into and out of collective agreements and works councils. In other words, whereas in Figures 1 through 6 (and Appendix Tables 1 through 4) we traced establishment/employment coverage of institutions in successive cross-sections, now the focus shifts to the behavior of individual plants with respect to the same institutional set: firstly, on a year-to-year basis; and, secondly, over the entire 20002008 interval.

\section{(Table 2 near here)}

Annual transitions are first provided in Table 2 for overlapping cross sections. We consider all possible movements: introductions, abolitions, and no changes in status. The latter category includes situations in which the institution in question either 'always' existed or 'never' existed. Thus, for example, from 2000 to 2001, we see that 92 percent of all establishments in Germany did not change their 2000 sectoral agreement status: in 44.9 (47.4) percent of the cases the sectoral agreement was always (never) present. By the end of the sample period, roughly the same share recording no change in status (i.e. 93 percent) is observed. Alternatively put, 7 to 8 percent of all establishments change their sectoral collective bargaining status over the course of a year, which nevertheless amounts to a fairly considerable amount of churning. Note also that while 44.9 percent of the entire cross section was covered by a sectoral agreement in 2000 and 2001, by the end of the sample period just 32.7 percent of those covered by sectoral bargaining in 2007 maintained that status in 2008. These movements represent a quite dramatic pattern of decline and are indicative of the erosion in sectoral bargaining. (Confirming the evidence presented earlier, the fall in sectoral agreements is, with one exception, monotonically decreasing over our sample period.) A reverse pattern obtains in respect of those plants never covered by a sectoral agreement: these climbed from 47.4 percent of the total in the first column to 60.7 percent in the last column of the table.

Firm-level agreements give the appearance of being an endangered species, with around 97 percent of establishments never being covered by this regime in the overlapping cross sections. Correspondingly, changes in firm-level collective bargaining appear tiny. But again observe that in all cases the proportions refer to the share of sample establishments so that there is in fact fairly considerable outward migration. And as far as works councils are concerned, we observe that they are present in roughly 10 percent of all establishments. Changes in status are fairly similar 
to those observed for firm-level agreements and hence are much smaller relatively speaking. ${ }^{13}$

Regional differences are most marked in the case of sectoral collective bargaining insofar as the share of 'never existing' agreements is much higher in the east by an almost 20 percentage point margin. Also note that the introduction of firmlevel agreements is consistently higher in the east. Regional differences in transitions in the case of works councils are altogether more muted.

(Table 3 near here)

These patterns in sectoral agreements, firm-level collective agreements, and worker representation generally carry over to the population of permanent stayers. The situation is depicted in Table 3. In particular, the 'always existing' sectoral agreement category is persistently higher among permanent stayers than for the whole cross-section (cf. the first column of Table 2), a natural result given that permanent stayers are on average of bigger size than the average establishment in the population.

(Table 4 near here)

Finally, in Table 4, we present eight-year transitions for the set of permanent stayers. As expected, for sectoral agreements there are now considerably more joiners and leavers than in the annual transition data. Thus, despite considerable institutional inertia, in approximately 20 percent of such cases establishments surveyed in both 2000 and 2008 do switch status. In other words, one establishment in five either leaves or joins sectoral agreements. The former predominate by about three to one. Unsurprisingly, changes in works council status over the sample period are much less common than for sectoral agreements, at around 6 percent of the total. But even these modest movements are larger than previously observed in the literature. In turn, given that only a small fraction of establishments are actually covered by a firm-level agreement, the reported share of bargaining cessations of 1.4 percent among all permanent stayers again shows that transitions out of firm bargaining are quite substantial - a little over one-half $(=1.4 / 2.6)$ of them will quit bargaining by 2008. Over this interval, east Germany records smaller gross changes (i.e. introductions plus abolitions) in sectoral bargaining and worker representation. 


\section{Concluding Remarks}

Our principal finding is that the erosion in sectoral collective bargaining first observed in the 1990s is ongoing. Moreover, the decline is more or less across the board, such that the similarities observed in disaggregations of the data (across permanent stayers, newly-founded firms, and closing establishments) in this regard are more common than the differences. One interesting subsidiary finding, however, is that closing establishments (if not their newly-founded counterparts) are no more likely to be covered by sectoral agreements than the generality of establishments. There are of course marked regional differences in levels of coverage and the process of change/erosion in also more pronounced in western Germany, We have even raised the possibility of a process of convergence, a latter day Drang nach Osten as it were.

We also detect some erosion in works council coverage. Although this trend is not always apparent in the data, it seems that Hassel's (1999) empirical finding is sustained. In other words, there is some indication of a decline in codetermination at plant level which may in turn support Hassel's distinctive conjecture, although there is no indication that works council coverage has held up better in sectors with collective agreements. Be that as it may, the dual system seems unequivocally to be in retreat.

Interestingly, there is no real suggestion of any material increase in firm-level collective bargaining. So this is not really where one should look for evidence of decentralization. Although we cannot directly answer whether decentralization is regulated or organized since our data do not allow us to pierce the veil of individual sectoral agreements, we might conclude from the decline in sectoral bargaining and the accompanying sharp rise in the establishment and employment coverage of a collective bargaining free zone that decentralization has been uncontrolled.

Finally, the transitions data generally support pattern of erosion identified here. They further indicate that there is no increasing trend out of sectoral agreements and into firm-level agreements. Indeed, the evidence is to the contrary. Nevertheless, the amount of switching between the two types of collective agreement is robust and further investigation of the dynamics may throw further light on the process of erosion. 


\section{Endnotes}

1. On these innovations, see Addison et al., 2009, and the references contained therein.

2. She reports that the share of employees in plants with works councils in the private sector fell from 52.4 percent in 1981 through 47.3 percent in 1990 to 41.6 percent in 1994.

3. Studies of works council coverage are typically separate. The best-known such studies have been those conducted by the Institute for Economic and Social Research/WSI (Wirtschafts- und Sozialwissenschaftliches Institut) of the HansBöckler-Stiftung. Every two years since 1998 the WSI has conducted representative nationwide surveys of works councils (see Schäfer, 2005). The surveys contain information on coverage as well as the attitude of works councils on collective bargaining issues, including the decentralization of collective bargaining through opening clauses and pacts for employment and competitiveness.

4. Lacking consistent data, we do not consider employee representation vehicles other than works councils. On the reach of such company-specific forms of employee representation, see Ellguth (2006); Ellguth and Kohaut (2008).

5. For as similar conclusion based on an analysis of concession bargaining under pacts for employment and competitiveness, see Massa-Wirth and Niechoj (2004).

6. For a detailed description of the dataset, see Fischer et al., 2009.

7. Three surveys within our sample period - those for 2000, 2004, and 2007 inquired as to the year of birth of all establishments.

8. Clearly, the two will diverge if the establishment fails to pay the social security tax in a timely fashion and this is a limitation of our approach. By the same token, our approach offers a consistent strategy since we also use the establishment register to identify deaths.

9. To be on the safe side, we actually checked for presence in the Betriebsdatei up to year $t-5$.

10. Observe that the five categories in the study by Addison et al. (2009) can easily be derived from this 13-group disaggregation.

11. As before, there were marked differences between east and west: in the western half of Germany the share of orienting firms (employees) rose from 23.2 percent (17.3 percent) to 28.3 percent (21.9 percent), whereas in the east declines in both shares were reported. Full details are available from the authors upon request. 
12. Corresponding values for joint coverage by firm-level agreements and works councils were 1.4 percent (5.8 percent) in 2000 and 1.0 percent (6.3 percent) in 2008. 13. We also investigated movements between types of collective bargaining. For Germany as a whole, movements out of sectoral into firm-level agreements declined through time: from 1.0 percent in 2000/2001 to 0.7 percent in 2007/2008. The same downward tendency was apparent in both halves of Germany. And at a time of declining sectoral agreements, considerable movement out of firm-level into sectoral collective bargaining is still observed. For Germany as a whole, 18.8 percent (14.5 percent) of establishments covered by a firm-level collective agreement in 2000 (2007) switched to a sectoral agreement in 2001 (2008). Such switching was always lower - oftentimes very much lower - in eastern than in western Germany. Full information is available from the authors upon request. 


\section{References}

Addison, John T., Alex Bryson, Paulino Teixeira, André Pahnke, and Lutz Bellmann. 2009. "The Extent of Collective Bargaining and Workplace Representation: Transitions between States and their Determinants. A Comparative Analysis of Germany and Great Britain.” CEP Discussion Paper No. 954. London School of Economics: Centre for Economic Performance, October.

Addison, John T., Claus Schnabel, and Joachim Wagner. 2007. "The (Parlous) State of German Unions.” Journal of Labor Research 28 (Winter): 3-18.

Bellmann, Lutz and Peter Ellguth. 2006. "Verbreitung von Betriebsräten und ihr Einfluss auf die betrieblichen Weiterbildung.” Jahrbücher für Nationalökonomie und Statistik 226 (5): 487-504.

Doellgast, Virginia and Ian Greer. 2007. "Vertical Disintegration and the Disorganization of German Industrial Relations.” British Journal of Industrial Relations 45 (March): 55-76.

Ingrid Artus (Hg.), Sabine Böhm (Hg.), Stefan Lücking (Hg.), Rainer Trinczek (Hg.)

Ellguth, Peter. 2006. "Betriebe ohne Betriebsrat. Verbreitung, Entwicklung und Charakteristika - unter Berücksichtigung betriebsspezifischer Formen der Mitarbeitervertretung” In Ingrid Artus, Sabine Böhm, Stefan Lücking and Rainer Trinczek (eds.), Betriebe ohne Betriebsrat. Informelle Interessenvertretung in Unternehmen. Frankfurt am Main: Campus Verlag, pp. 43-80.

Ellguth, Peter and Susanne Kohaut. 2008. "Tarifbindung und betriebliche Interessenvertretung. Aktuelle Ergebnisse aus dem IAB-Betriebspanel 2007.” WSIMitteilungen 61 (9): 515-519.

Ellguth, Peter and Susanne Kohaut. 2010. “Tarifbindung und betriebliche Interessenvertretung - aktuelle Ergebnisse aus dem IAB-Betriebspanel 2009.” WSIMitteilungen 63 (4): 204-209.

Fischer, Gabriele, Florian Janik, Dana Müller, and Alexandra Schmucker. 2009. "The IAB Establishment Panel: Things Users Should Know.” Schmollers Jahrbuch 129 (1): 133-148.

Frege, Carola M. 2003. “Transforming German Workplace Relations: Quo Vadis Cooperation?” Economic and Industrial Democracy 24 (August): 317-347.

Hassel, Anke. 1999, "The Erosion of the German System of Industrial Relations.” British Journal of Industrial Relations 37 (September): 483-505.

Hassel, Anke. 2002. “The Erosion Continues: Reply [to Klikauer].” British Journal of Industrial Relations 40 (June): 309-317.

Klikauer, Thomas. 2002. "Stability in Germany's Industrial Relations: A Critique on Hassel’s Erosion Thesis.” British Journal of Industrial Relations 40 (June): 295-308. 
Kohaut, Susanne and Claus Schnabel. 2003a. "Tarifverträge - nein danke? Ausmaß und Einflussfaktoren der Tarifbindung west- und ostdeutscher Betriebe. ” Jahrbücher für Nationalalökonomie und Statistik 223 (May); 312-333.

Kohaut, Susanne and Claus Schnabel. 2003b. "Zur Erosion des Flächentarifvertrags: Ausmaß, Einflussfaktoren und Gegenmaßnahmen.” Industrielle Beziehungen 10 (2): 193-219.

Kohaut, Susanne and Claus Schnabel. 2007. "Tarifliche Öffnungsklauseln: Verbreitung, Inanspruchnahme und Bedeutung.” Sozialer Fortschritt 56 (2): 33-40.

Kohaut, Susanne and Peter Ellguth. 2008. Neue gegründete Betriebe sind seltener tarifbebunden.” IAB-Kurzbericht16: 1-8.

Massa-Wirth, Heiko and Torsten Niechoj. 2004. "Supranational Coordination but National Fragmentation: Interplay of European Economic Policy and Firm-Level Pacts in Germany.” Düsseldorf: Das Wirtschafts- und Sozialwissenschaftliche Institut (WSI) der Hans-Böckler-Stiftung. Available online at http://poloekdvpw.mpifg.de/e_documents/publikationen/Massa-wirth\%20Niechoj\%20-

\%20Supranational\%20Coordination.pdf

Schäfer, Claus. 2005. "Die WSI-Befragung von Betriebs- und Personalräten 2004/2005 - ein Überblick.” WSI-Mitteilungen 12 : 669-676.

Silvia, Stephen J. and Wolfgang Schroeder. 2007. "Why Are German Employers' Associations Declining? Arguments and Evidence” Comparative Political Studies 40 (December): 1433-1459.

Thelen, Katherine. 1991. Union of Parts: Labor Politics in Postwar Germany. Ithaca, NY: Cornell University Press.

Thelen, Katherine and Christa Van Wijnbergen. 2003. "The Paradox of Globalization: Labor relatiobnsd in Germany and Beyond." Comparative Political Studies 36 (October): 859-880.

Streeck, Wolfgang. 2001. "The Transformation of Corporate Organization in Europe: An Overview.” Cologne: Max-Planck Institute for the Study of Societies.

Streeck, Wolfgang and Katherine Thelen. 2004. "Introduction: Institutional Change in Advanced Political Economies.” In Wolfgang Streeck and Katherine Thelen (eds.), Beyond Continuity: Institutional Change in Advanced Political Economies. New York: Oxford University Press, pp. 1-39. 
TABLE 1

The Categories of the Sample and their Definitions

\begin{tabular}{|c|c|c|c|c|}
\hline \# & Main categories & \# & Subcategories & Definitions: in a given year $t$. an establishment $j$ in the sample either:- \\
\hline 2 & permanent stayer & 3 & permanent stayer & is observed in every single year of the interval 2000-2008 \\
\hline \multirow[t]{4}{*}{4} & \multirow[t]{4}{*}{ 1-period-stayer } & 5 & 1-period-stayer/birth/leaver & is only observed in $t$ and was born in $t-1$ \\
\hline & & 6 & 1-period-stayer/birth/dead 'A' & is only observed in $t$ and was born in $t-1$ and dies in $t+1$ \\
\hline & & 7 & 1-period-stayer/birth/dead 'B' & is only observed in $t$ and was born in $t-1$ and dies after $t+1$ \\
\hline & & 8 & 1-period-stayer/leaver & is only observed in $t$ and is a continuing establishment and leaves the panel in $t+1$ \\
\hline \multirow[t]{3}{*}{5} & \multirow[t]{3}{*}{ Exit } & 11 & exit/leaver & was observed at least once in the interval between 1999 and $t$ and leaves the panel in $t+1$ \\
\hline & & 12 & exit/dead 'A' & was observed at least once in the interval between 1999 and $t$ and dies in $t+1$ \\
\hline & & 13 & exit/dead 'B' & was observed at least once in the interval between 1999 and $t$, leaves the panel in $t+1$, and dies after $t+1$ \\
\hline
\end{tabular}


TABLE 2

Annual Transitions in Collective Bargaining and Works Council Status for Germany and by Broad Region, 2000-2004, All Establishments, Weighted Data

\begin{tabular}{|c|c|c|c|c|c|c|c|c|c|c|c|c|c|}
\hline & & \multicolumn{3}{|c|}{ From 2000 to 2001} & \multicolumn{3}{|c|}{ From 2001 to 2002} & \multicolumn{3}{|c|}{ From 2002 to 2003} & \multicolumn{3}{|c|}{ From 2003 to 2004} \\
\hline & & Germany & West & East & Germany & West & East & Germany & West & East & Germany & West & East \\
\hline \multirow{6}{*}{ 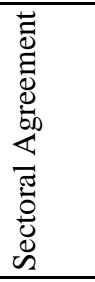 } & Always existing & $44.9 \%$ & $50.1 \%$ & $25.5 \%$ & $42.1 \%$ & $47.8 \%$ & $22.3 \%$ & $42.4 \%$ & $47.3 \%$ & $21.0 \%$ & $38.8 \%$ & $43.4 \%$ & $19.8 \%$ \\
\hline & Introduced & $3.6 \%$ & $3.8 \%$ & $2.5 \%$ & $2.9 \%$ & $3.3 \%$ & $1.5 \%$ & $2.9 \%$ & $3.0 \%$ & $2.8 \%$ & $2.8 \%$ & $2.7 \%$ & $3.1 \%$ \\
\hline & Abolished & $4.2 \%$ & $4.7 \%$ & $2.4 \%$ & $5.0 \%$ & $5.1 \%$ & $4.4 \%$ & $4.5 \%$ & $4.9 \%$ & $3.0 \%$ & $4.6 \%$ & $5.3 \%$ & $1.6 \%$ \\
\hline & Never existing & $47.4 \%$ & $41.3 \%$ & $69.6 \%$ & $50.1 \%$ & $43.8 \%$ & $71.8 \%$ & $50.1 \%$ & $44.8 \%$ & $73.2 \%$ & $53.9 \%$ & $48.6 \%$ & $75.6 \%$ \\
\hline & Net change & $-0.6 \%$ & $-0.8 \%$ & $0.1 \%$ & $-2.1 \%$ & $-1.8 \%$ & $-2.9 \%$ & $-1.6 \%$ & $-1.9 \%$ & $-0.3 \%$ & $-1.8 \%$ & $-2.6 \%$ & $1.5 \%$ \\
\hline & $N$ & 589,260 & 462,960 & 126,301 & 655,613 & 508,618 & 146,994 & 644,837 & 524,244 & 120,593 & 719,959 & 579,002 & 140,958 \\
\hline \multirow{6}{*}{ 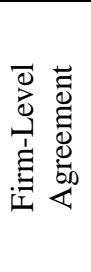 } & Always existing & $1.6 \%$ & $1.1 \%$ & $3.6 \%$ & $1.8 \%$ & $1.3 \%$ & $3.3 \%$ & $1.5 \%$ & $1.1 \%$ & $3.2 \%$ & $1.3 \%$ & $1.0 \%$ & $2.7 \%$ \\
\hline & Introduced & $1.0 \%$ & $0.9 \%$ & $1.1 \%$ & $0.8 \%$ & $0.8 \%$ & $1.0 \%$ & $0.5 \%$ & $0.4 \%$ & $0.9 \%$ & $0.7 \%$ & $0.6 \%$ & $1.0 \%$ \\
\hline & Abolished & $0.8 \%$ & $0.8 \%$ & $1.0 \%$ & $0.9 \%$ & $1.0 \%$ & $0.6 \%$ & $0.6 \%$ & $0.5 \%$ & $1.0 \%$ & $0.4 \%$ & $0.3 \%$ & $0.9 \%$ \\
\hline & Never existing & $96.5 \%$ & $97.2 \%$ & $94.3 \%$ & $96.5 \%$ & $96.9 \%$ & $95.1 \%$ & $97.4 \%$ & $98.0 \%$ & $94.9 \%$ & $97.6 \%$ & $98.1 \%$ & $95.5 \%$ \\
\hline & Net change & $0.1 \%$ & $0.1 \%$ & $0.1 \%$ & $-0.1 \%$ & $-0.3 \%$ & $0.3 \%$ & $-0.1 \%$ & $-0.1 \%$ & $-0.1 \%$ & $0.2 \%$ & $0.3 \%$ & $0.1 \%$ \\
\hline & $N$ & 589,261 & 462,960 & 126,301 & 655,612 & 508,618 & 146,994 & 644,837 & 524,245 & 120,593 & 719,959 & 579,001 & 140,957 \\
\hline \multirow{6}{*}{ 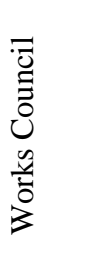 } & Always existing & $10.9 \%$ & $11.1 \%$ & $9.9 \%$ & $8.2 \%$ & $8.4 \%$ & $77.6 \%$ & $8.7 \%$ & $8.8 \%$ & $7.9 \%$ & $7.8 \%$ & $7.7 \%$ & $8.1 \%$ \\
\hline & Introduced & $0.0 \%$ & $0.0 \%$ & $0.0 \%$ & $1.4 \%$ & $1.5 \%$ & $1.2 \%$ & $0.7 \%$ & $0.7 \%$ & $0.4 \%$ & $0.6 \%$ & $0.6 \%$ & $0.4 \%$ \\
\hline & Abolished & $0.0 \%$ & $0.0 \%$ & $0.0 \%$ & $2.6 \%$ & $2.7 \%$ & $2.3 \%$ & $0.8 \%$ & $0.9 \%$ & $0.3 \%$ & $0.7 \%$ & $0.7 \%$ & $0.8 \%$ \\
\hline & Never existing & $89.1 \%$ & $88.9 \%$ & $90.1 \%$ & $87.8 \%$ & $87.5 \%$ & $88.9 \%$ & $89.9 \%$ & $89.6 \%$ & $91.4 \%$ & $90.9 \%$ & $91.0 \%$ & $90.7 \%$ \\
\hline & Net change & $0.0 \%$ & $0.0 \%$ & $0.0 \%$ & $-1.2 \%$ & $-1.2 \%$ & $-1.2 \%$ & $-0.1 \%$ & $-0.1 \%$ & $0.0 \%$ & $-0.2 \%$ & $-0.1 \%$ & $-0.4 \%$ \\
\hline & $N$ & 589,261 & 462,960 & 126,301 & 654,156 & 507,359 & 146,795 & 645,838 & 525,245 & 120,593 & 716,219 & 575,637 & 140,582 \\
\hline
\end{tabular}


TABLE 2 (Cont.)

\begin{tabular}{|c|c|c|c|c|c|c|c|c|c|c|c|c|c|}
\hline & & \multicolumn{3}{|c|}{ From 2004 to 2005} & \multicolumn{3}{|c|}{ From 2005 to 2006} & \multicolumn{3}{|c|}{ From 2006 to 2007} & \multicolumn{3}{|c|}{ From 2007 to 2008} \\
\hline & & Germany & West & East & Germany & West & East & Germany & West & East & Germany & West & East \\
\hline \multirow{6}{*}{ 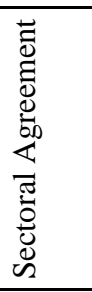 } & Always existing & $36.7 \%$ & $40.7 \%$ & $20.3 \%$ & $36.2 \%$ & $39.7 \%$ & $21.3 \%$ & $34.1 \%$ & $37.7 \%$ & $18.8 \%$ & $32.7 \%$ & $35.9 \%$ & $20.3 \%$ \\
\hline & Introduced & $3.4 \%$ & $3.4 \%$ & $3.3 \%$ & $2.0 \%$ & $2.0 \%$ & $2.1 \%$ & $2.3 \%$ & $2.3 \%$ & $2.4 \%$ & $3.2 \%$ & $3.6 \%$ & $1.7 \%$ \\
\hline & Abolished & $3.3 \%$ & $3.6 \%$ & $2.0 \%$ & $4.3 \%$ & $4.6 \%$ & $2.8 \%$ & $3.8 \%$ & $4.2 \%$ & $2.0 \%$ & $3.3 \%$ & $3.4 \%$ & $2.9 \%$ \\
\hline & Never existing & $56.6 \%$ & $52.3 \%$ & $74.4 \%$ & $57.5 \%$ & $53.7 \%$ & $73.8 \%$ & $59.8 \%$ & $55.8 \%$ & $76.8 \%$ & $60.7 \%$ & $57.0 \%$ & $75.1 \%$ \\
\hline & Net change & $0.1 \%$ & $-0.2 \%$ & $1.3 \%$ & $-2.3 \%$ & $-2.7 \%$ & $-0.7 \%$ & $-1.5 \%$ & $-1.9 \%$ & $0.4 \%$ & $-0.1 \%$ & $0.2 \%$ & $-1.2 \%$ \\
\hline & $N$ & 675,115 & 545,698 & 129,777 & 699,631 & 566,607 & 133,023 & 687,950 & 557,298 & 130,653 & 719,404 & 571,266 & 148,137 \\
\hline \multirow{6}{*}{ 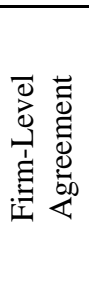 } & Always existing & $2.0 \%$ & $1.6 \%$ & $3.3 \%$ & $1.6 \%$ & $1.2 \%$ & $3.0 \%$ & $1.5 \%$ & $1.1 \%$ & $3.4 \%$ & $1.7 \%$ & $1.2 \%$ & $3.9 \%$ \\
\hline & Introduced & $0.6 \%$ & $0.4 \%$ & $1.4 \%$ & $0.5 \%$ & $0.4 \%$ & $0.9 \%$ & $0.6 \%$ & $0.4 \%$ & $1.2 \%$ & $0.6 \%$ & $0.7 \%$ & $0.5 \%$ \\
\hline & Abolished & $0.5 \%$ & $0.5 \%$ & $0.5 \%$ & $0.6 \%$ & $0.6 \%$ & $0.7 \%$ & $0.7 \%$ & $0.6 \%$ & $1.0 \%$ & $0.6 \%$ & $0.5 \%$ & $0.6 \%$ \\
\hline & Never existing & $97.0 \%$ & $97.5 \%$ & $94.8 \%$ & $97.4 \%$ & $97.8 \%$ & $95.5 \%$ & $97.3 \%$ & $98.0 \%$ & $94.4 \%$ & $97.1 \%$ & $97.6 \%$ & $95.0 \%$ \\
\hline & Net change & $0.1 \%$ & $-0.1 \%$ & $0.9 \%$ & $-0.1 \%$ & $-0.1 \%$ & $0.2 \%$ & $-0.1 \%$ & $-0.2 \%$ & $0.1 \%$ & $0.1 \%$ & $0.1 \%$ & $-0.1 \%$ \\
\hline & $N$ & 675,155 & 545,338 & 129,777 & 699,630 & 566,607 & 133,022 & 687,950 & 557,298 & 130,652 & 719,403 & 571,267 & 148,137 \\
\hline \multirow{6}{*}{ 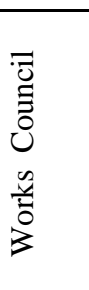 } & Always existing & $8.4 \%$ & $8.5 \%$ & $7.8 \%$ & $8.2 \%$ & $8.2 \%$ & $8.4 \%$ & $8.1 \%$ & $8.2 \%$ & $7.8 \%$ & $7.7 \%$ & $7.8 \%$ & $7.4 \%$ \\
\hline & Introduced & $0.5 \%$ & $0.5 \%$ & $0.6 \%$ & $0.4 \%$ & $0.4 \%$ & $0.2 \%$ & $0.4 \%$ & $0.4 \%$ & $0.2 \%$ & $0.6 \%$ & $0.7 \%$ & $0.3 \%$ \\
\hline & Abolished & $0.3 \%$ & $0.3 \%$ & $0.4 \%$ & $0.8 \%$ & $0.8 \%$ & $0.5 \%$ & $0.3 \%$ & $0.3 \%$ & $0.3 \%$ & $0.4 \%$ & $0.4 \%$ & $0.4 \%$ \\
\hline & Never existing & $90.8 \%$ & $90.7 \%$ & $91.2 \%$ & $90.6 \%$ & $90.5 \%$ & $90.9 \%$ & $91.2 \%$ & $91.1 \%$ & $91.7 \%$ & $91.2 \%$ & $91.1 \%$ & $91.9 \%$ \\
\hline & Net change & $0.2 \%$ & $0.2 \%$ & $0.1 \%$ & $-0.4 \%$ & $-0.4 \%$ & $-0.4 \%$ & $0.1 \%$ & $0.1 \%$ & $-0.1 \%$ & $0.2 \%$ & $0.3 \%$ & $-0.1 \%$ \\
\hline & $N$ & 675,129 & 545,353 & 129,778 & 699,630 & 566,607 & 133,023 & 687,736 & 557,303 & 130,432 & 719,642 & 571,505 & 148,137 \\
\hline
\end{tabular}


TABLE 3

Annual Transitions in Collective Bargaining and Works Council Status for Germany and by Broad Region, 2000-2004, Permanent Stayers, Weighted Data

\begin{tabular}{|c|c|c|c|c|c|c|c|c|c|c|c|c|c|}
\hline & & \multicolumn{3}{|c|}{ From 2000 to 2001} & \multicolumn{3}{|c|}{ From 2001 to 2002} & \multicolumn{3}{|c|}{ From 2002 to 2003} & \multicolumn{3}{|c|}{ From 2003 to 2004} \\
\hline & & Germany & West & East & Germany & West & East & Germany & West & East & Germany & West & East \\
\hline \multirow{6}{*}{ 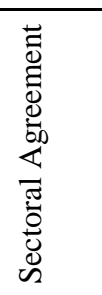 } & Always existing & $46.7 \%$ & $53.3 \%$ & $26.0 \%$ & $44.2 \%$ & $52.0 \%$ & $23.1 \%$ & $46.3 \%$ & $53.6 \%$ & $23.7 \%$ & $44.1 \%$ & $51.4 \%$ & $22.8 \%$ \\
\hline & Introduced & $2.8 \%$ & $2.5 \%$ & $3.5 \%$ & $2.9 \%$ & $3.3 \%$ & $1.9 \%$ & $2.5 \%$ & $2.7 \%$ & $1.9 \%$ & $1.5 \%$ & $1.5 \%$ & $1.5 \%$ \\
\hline & Abolished & $2.7 \%$ & $3.1 \%$ & $1.7 \%$ & $4.6 \%$ & $4.6 \%$ & $4.6 \%$ & $3.4 \%$ & $3.8 \%$ & $2.3 \%$ & $4.1 \%$ & $5.0 \%$ & $1.5 \%$ \\
\hline & Never existing & $47.9 \%$ & $41.1 \%$ & $68.8 \%$ & $48.2 \%$ & $40.1 \%$ & $70.3 \%$ & $47.8 \%$ & $39.9 \%$ & $72.1 \%$ & $50.2 \%$ & $42.1 \%$ & $74.2 \%$ \\
\hline & Net change & $0.0 \%$ & $-0.5 \%$ & $1.8 \%$ & $-1.7 \%$ & $-1.3 \%$ & $-2.7 \%$ & $-1.0 \%$ & $-1.2 \%$ & $-0.5 \%$ & $-2.6 \%$ & $-3.5 \%$ & $0.0 \%$ \\
\hline & $N$ & 151,853 & 114,735 & 37,118 & 157,265 & 114,924 & 42,341 & 155,478 & 117,424 & 38,054 & 148,167 & 110,602 & 37,565 \\
\hline \multirow{6}{*}{ 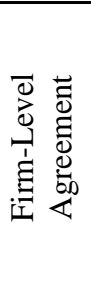 } & Always existing & $2.3 \%$ & $1.5 \%$ & $4.6 \%$ & $2.1 \%$ & $1.2 \%$ & $4.6 \%$ & $1.3 \%$ & $0.8 \%$ & $3.0 \%$ & $1.8 \%$ & $1.3 \%$ & $3.2 \%$ \\
\hline & Introduced & $1.4 \%$ & $1.6 \%$ & $1.1 \%$ & $0.3 \%$ & $0.2 \%$ & $0.4 \%$ & $0.5 \%$ & $0.5 \%$ & $0.5 \%$ & $1.2 \%$ & $1.5 \%$ & $0.3 \%$ \\
\hline & Abolished & $0.3 \%$ & $0.0 \%$ & $1.2 \%$ & $1.2 \%$ & $1.3 \%$ & $0.9 \%$ & $0.8 \%$ & $0.7 \%$ & $1.0 \%$ & $0.2 \%$ & $0.1 \%$ & $0.4 \%$ \\
\hline & Never existing & $95.9 \%$ & $96.9 \%$ & $93.1 \%$ & $96.5 \%$ & $97.3 \%$ & $94.1 \%$ & $97.4 \%$ & $98.1 \%$ & $95.5 \%$ & $96.8 \%$ & $97.0 \%$ & $96.1 \%$ \\
\hline & Net change & $1.1 \%$ & $1.5 \%$ & $-0.2 \%$ & $-0.9 \%$ & $-1.1 \%$ & $-0.4 \%$ & $-0.2 \%$ & $-0.2 \%$ & $-0.5 \%$ & $1.0 \%$ & $1.4 \%$ & $-0.1 \%$ \\
\hline & $N$ & 151,853 & 114,734 & 37,118 & 157,265 & 114,924 & 42,341 & 155,478 & 117,424 & 38,054 & 148,166 & 110,603 & 37,564 \\
\hline \multirow{6}{*}{ 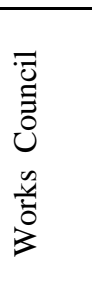 } & Always existing & $11.1 \%$ & $10.7 \%$ & $12.4 \%$ & $7.6 \%$ & $7.6 \%$ & $7.7 \%$ & $8.5 \%$ & $8.8 \%$ & $7.8 \%$ & $8.9 \%$ & $9.1 \%$ & $8.3 \%$ \\
\hline & Introduced & $0.0 \%$ & $0.0 \%$ & $0.0 \%$ & $0.9 \%$ & $1.1 \%$ & $0.5 \%$ & $0.7 \%$ & $0.9 \%$ & $0.1 \%$ & $0.2 \%$ & $0.1 \%$ & $0.3 \%$ \\
\hline & Abolished & $0.0 \%$ & $0.0 \%$ & $0.0 \%$ & $3.1 \%$ & $3.2 \%$ & $2.8 \%$ & $0.4 \%$ & $0.4 \%$ & $0.3 \%$ & $0.4 \%$ & $0.3 \%$ & $0.6 \%$ \\
\hline & Never existing & $88.9 \%$ & $89.3 \%$ & $87.6 \%$ & $88.4 \%$ & $88.1 \%$ & $89.1 \%$ & $90.4 \%$ & $89.9 \%$ & $91.8 \%$ & $90.5 \%$ & $90.5 \%$ & $90.8 \%$ \\
\hline & Net change & $0.0 \%$ & $0.0 \%$ & $0.0 \%$ & $-2.1 \%$ & $-2.1 \%$ & $-2.3 \%$ & $0.3 \%$ & $0.5 \%$ & $-0.2 \%$ & $-0.2 \%$ & $-0.2 \%$ & $-0.3 \%$ \\
\hline & $N$ & 151,853 & 114,735 & 37,118 & 157,265 & 114,924 & 42,341 & 155,479 & 117,457 & 38,054 & 148,167 & 110,602 & 37,565 \\
\hline
\end{tabular}


TABLE 3 (Cont.)

\begin{tabular}{|c|c|c|c|c|c|c|c|c|c|c|c|c|c|}
\hline & & \multicolumn{3}{|c|}{ From 2004 to 2005} & \multicolumn{3}{|c|}{ From 2005 to 2006} & \multicolumn{3}{|c|}{ From 2006 to 2007} & \multicolumn{3}{|c|}{ From 2007 to 2008} \\
\hline & & Germany & West & East & Germany & West & East & Germany & West & East & Germany & West & East \\
\hline \multirow{6}{*}{ 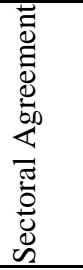 } & Always existing & $42.6 \%$ & $48.4 \%$ & $24.2 \%$ & $41.2 \%$ & $46.6 \%$ & $24.5 \%$ & $37.7 \%$ & $42.8 \%$ & $21.7 \%$ & $36.6 \%$ & $41.4 \%$ & $22.6 \%$ \\
\hline & Introduced & $3.0 \%$ & $2.3 \%$ & $4.9 \%$ & $1.1 \%$ & $1.3 \%$ & $0.5 \%$ & $2.0 \%$ & $1.7 \%$ & $2.9 \%$ & $3.5 \%$ & $4.3 \%$ & $1.3 \%$ \\
\hline & Abolished & $2.8 \%$ & $2.9 \%$ & $2.2 \%$ & $3.3 \%$ & $3.1 \%$ & $3.7 \%$ & $4.6 \%$ & $5.8 \%$ & $0.8 \%$ & $3.5 \%$ & $3.2 \%$ & $4.2 \%$ \\
\hline & Never existing & $51.7 \%$ & $46.4 \%$ & $68.7 \%$ & $54.4 \%$ & $48.9 \%$ & $71.3 \%$ & $55.7 \%$ & $49.7 \%$ & $74.5 \%$ & $56.4 \%$ & $51.0 \%$ & $71.9 \%$ \\
\hline & Net change & $0.2 \%$ & $-0.6 \%$ & $2.7 \%$ & $-2.1 \%$ & $-1.8 \%$ & $-3.2 \%$ & $-2.6 \%$ & $-4.1 \%$ & $2.1 \%$ & $0.0 \%$ & $1.1 \%$ & $-2.9 \%$ \\
\hline & $N$ & 150,288 & 114,463 & 35,824 & 148,835 & 112,449 & 36,385 & 147,964 & 112,206 & 35,758 & 151,394 & 112,196 & 39,198 \\
\hline \multirow{5}{*}{ 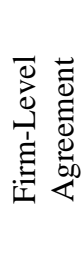 } & Introduced & $0.3 \%$ & $0.0 \%$ & $1.2 \%$ & $0.3 \%$ & $0.1 \%$ & $0.9 \%$ & $0.7 \%$ & $0.6 \%$ & $1.2 \%$ & $0.3 \%$ & $0.1 \%$ & $0.8 \%$ \\
\hline & Abolished & $0.1 \%$ & $0.1 \%$ & $0.3 \%$ & $0.4 \%$ & $0.4 \%$ & $0.6 \%$ & $1.3 \%$ & $1.3 \%$ & $1.2 \%$ & $0.7 \%$ & $0.7 \%$ & $0.7 \%$ \\
\hline & Never existing & $96.9 \%$ & $97.4 \%$ & $95.3 \%$ & $96.7 \%$ & $97.4 \%$ & $94.8 \%$ & $96.1 \%$ & $97.0 \%$ & $93.5 \%$ & $96.9 \%$ & $98.2 \%$ & $93.4 \%$ \\
\hline & Net change & $0.2 \%$ & $-0.1 \%$ & $0.9 \%$ & $-0.2 \%$ & $-0.3 \%$ & $0.3 \%$ & $-0.6 \%$ & $-0.7 \%$ & $0.0 \%$ & $-0.4 \%$ & $-0.6 \%$ & $0.1 \%$ \\
\hline & $N$ & 150,287 & 114,463 & 35,824 & 148,835 & 112,449 & 36,385 & 147,965 & 112,206 & 35,758 & 151,394 & 112,196 & 39,198 \\
\hline \multirow{5}{*}{ 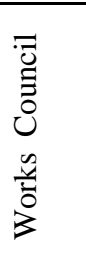 } & Always existing & $8.4 \%$ & $8.6 \%$ & $7.6 \%$ & $8.6 \%$ & $8.7 \%$ & $8.2 \%$ & $9.4 \%$ & $9.9 \%$ & $7.7 \%$ & $8.8 \%$ & $9.1 \%$ & $8.0 \%$ \\
\hline & Introduced & $0.4 \%$ & $0.4 \%$ & $0.3 \%$ & $0.5 \%$ & $0.6 \%$ & $0.1 \%$ & $0.2 \%$ & $0.2 \%$ & $0.1 \%$ & $0.9 \%$ & $1.1 \%$ & $0.5 \%$ \\
\hline & Never existing & $90.7 \%$ & $90.4 \%$ & $91.8 \%$ & $90.1 \%$ & $89.8 \%$ & $91.2 \%$ & $90.4 \%$ & $89.8 \%$ & $92.0 \%$ & $90.0 \%$ & $89.5 \%$ & $91.5 \%$ \\
\hline & Net change & $-0.2 \%$ & $-0.2 \%$ & $0.0 \%$ & $-0.3 \%$ & $-0.4 \%$ & $-0.3 \%$ & $0.1 \%$ & $0.1 \%$ & $-0.2 \%$ & $0.6 \%$ & $0.7 \%$ & $0.4 \%$ \\
\hline & $N$ & 150,287 & 114,463 & 35,824 & 148,835 & 112,450 & 36,385 & 147,964 & 112,206 & 35,758 & 151,394 & 112,196 & 39,198 \\
\hline
\end{tabular}


TABLE 4

Eight-year Transitions in Collective Bargaining and Works Council Status for Germany and by Broad Region, 2000-2008, Permanent Stayers, Weighted Data

\begin{tabular}{|r|r|r|r|r|r|r|r|r|r|}
\hline & \multicolumn{3}{|c|}{ Sectoral Agreement } & \multicolumn{2}{|c|}{ Firm-level Agreement } & \multicolumn{3}{|c|}{ Works Council } \\
\hline & Germany & \multicolumn{1}{|c|}{ West } & East & Germany & West & East & Germany & West & East \\
\hline Always existing & $35.1 \%$ & $40.8 \%$ & $18.9 \%$ & $1.2 \%$ & $0.6 \%$ & $3.1 \%$ & $8.3 \%$ & $8.5 \%$ & $7.8 \%$ \\
\hline Introduced & $5.0 \%$ & $5.0 \%$ & $5.0 \%$ & $1.2 \%$ & $0.5 \%$ & $2.9 \%$ & $1.4 \%$ & $1.7 \%$ & $0.6 \%$ \\
\hline Abolished & $15.0 \%$ & $16.4 \%$ & $11.1 \%$ & $1.4 \%$ & $1.0 \%$ & $2.6 \%$ & $4.4 \%$ & $4.1 \%$ & $5.5 \%$ \\
\hline Never existing & $44.9 \%$ & $37.9 \%$ & $64.9 \%$ & $96.2 \%$ & $97.9 \%$ & $91.4 \%$ & $85.8 \%$ & $85.7 \%$ & $86.1 \%$ \\
\hline Net change & $-10.1 \%$ & $-11.5 \%$ & $-6.2 \%$ & $-0.2 \%$ & $-0.4 \%$ & $0.3 \%$ & $-3.0 \%$ & $-2.4 \%$ & $-4.9 \%$ \\
\hline$N$ & 151,394 & 112,196 & 39,198 & 151,394 & 112,196 & 39,198 & 151,394 & 112,196 & 39,198 \\
\hline
\end{tabular}




\section{APPENDIX TABLE 1}

Collective Bargaining and Works Council Coverage for Germany and by Broad Region, 2000-2008, All Establishments, Weighted Data

\begin{tabular}{|c|c|c|c|c|c|c|c|c|c|c|c|}
\hline \multirow[b]{3}{*}{ Year } & \multirow[b]{3}{*}{ Region } & \multicolumn{6}{|c|}{ Collective Agreement Status } & \multirow{2}{*}{\multicolumn{2}{|c|}{$\begin{array}{l}\text { Works } \\
\text { Council }\end{array}$}} & \multirow{2}{*}{\multicolumn{2}{|c|}{ Totals }} \\
\hline & & \multicolumn{2}{|c|}{$\begin{array}{c}\text { Sectoral } \\
\text { Agreement }\end{array}$} & \multicolumn{2}{|c|}{$\begin{array}{l}\text { Firm-Level } \\
\text { Agreement }\end{array}$} & \multicolumn{2}{|c|}{$\begin{array}{c}\text { No } \\
\text { Agreement }\end{array}$} & & & & \\
\hline & & I & II & $\mathrm{I}$ & II & I & II & I & II & I & II \\
\hline \multirow[t]{3}{*}{2000} & Germany & $47.3 \%$ & $57.3 \%$ & $2.5 \%$ & $6.8 \%$ & $50.1 \%$ & $35.9 \%$ & $10.3 \%$ & $45.2 \%$ & 855,135 & $20,063,803$ \\
\hline & West & $52.3 \%$ & $60.9 \%$ & $2.2 \%$ & $6.2 \%$ & $45.5 \%$ & $32.9 \%$ & $10.4 \%$ & $46.9 \%$ & 687,189 & $16,740,291$ \\
\hline & East & $26.9 \%$ & $39.3 \%$ & $4.1 \%$ & $9.9 \%$ & $69.0 \%$ & $50.8 \%$ & $10.1 \%$ & $36.8 \%$ & 167,946 & \\
\hline \multirow[t]{3}{*}{2001} & Germany & $45.8 \%$ & $57.3 \%$ & $2.6 \%$ & $9.2 \%$ & $51.6 \%$ & $35.1 \%$ & $10.2 \%$ & $46.0 \%$ & 823,286 & \\
\hline & West & $50.6 \%$ & $61.5 \%$ & $2.2 \%$ & $6.5 \%$ & $47.3 \%$ & & & $47.7 \%$ & & \\
\hline & East & $26.5 \%$ & $37.2 \%$ & $4.4 \%$ & $12.9 \%$ & $69.1 \%$ & $49.8 \%$ & $9.9 \%$ & $37.5 \%$ & 163,433 & \\
\hline \multirow[t]{3}{*}{2002} & Germany & $44.2 \%$ & $56.8 \%$ & $2.5 \%$ & $7.0 \%$ & $53.3 \%$ & $36.2 \%$ & $9.2 \%$ & $45.8 \%$ & & \\
\hline & & $9.1 \%$ & $60.7 \%$ & $2.1 \%$ & $6.0 \%$ & & & & & & \\
\hline & East & $23.6 \%$ & $36.6 \%$ & $4.4 \%$ & $11.8 \%$ & $72.0 \%$ & $51.6 \%$ & $9.0 \%$ & $38.5 \%$ & 161,016 & 3,2 \\
\hline \multirow[t]{3}{*}{2003} & Germany & $43.2 \%$ & $55.9 \%$ & $2.1 \%$ & $7.1 \%$ & $54.8 \%$ & $37.0 \%$ & $8.9 \%$ & $44.7 \%$ & 841,910 & 19,6 \\
\hline & West & $48.3 \%$ & $59.6 \%$ & $1.7 \%$ & $6.5 \%$ & $50.0 \%$ & & $9.0 \%$ & $46.2 \%$ & & \\
\hline & East & $22.0 \%$ & & $3.6 \%$ & $10.1 \%$ & & & & & & \\
\hline \multirow[t]{3}{*}{2004} & Germany & $40.0 \%$ & $54.4 \%$ & $2.4 \%$ & $7.3 \%$ & $57.6 \%$ & $38.4 \%$ & $8.6 \%$ & $44.0 \%$ & 702 & \\
\hline & West & $44.3 \%$ & $58.1 \%$ & $2.1 \%$ & $6.7 \%$ & $53.6 \%$ & $35.3 \%$ & $8.7 \%$ & $45.3 \%$ & 337 & \\
\hline & East & $22.3 \%$ & $35.7 \%$ & $3.5 \%$ & $10.2 \%$ & $74.2 \%$ & & $8.3 \%$ & $37.4 \%$ & & \\
\hline \multirow[t]{3}{*}{2005} & Germany & $39.8 \%$ & $52.9 \%$ & $2.6 \%$ & $7.7 \%$ & $57.6 \%$ & $39.4 \%$ & $9.0 \%$ & $43.5 \%$ & 826,191 & \\
\hline & West & $43.7 \%$ & $56.2 \%$ & $2.2 \%$ & $7.2 \%$ & $54.1 \%$ & $36.7 \%$ & $9.2 \%$ & $45.0 \%$ & ,722 & 16 \\
\hline & East & $23.5 \%$ & $36.2 \%$ & $4.3 \%$ & $10.6 \%$ & $72.3 \%$ & $53.2 \%$ & $8.2 \%$ & $36.1 \%$ & 157,469 & $3,194,390$ \\
\hline \multirow[t]{3}{*}{2006} & Germany & $37.4 \%$ & $50.5 \%$ & $2.2 \%$ & $7.6 \%$ & $60.4 \%$ & & $8.7 \%$ & $42.6 \%$ & & \\
\hline & West & $40.7 \%$ & $53.6 \%$ & $1.7 \%$ & $6.8 \%$ & $57.6 \%$ & $39.6 \%$ & $8.8 \%$ & $43.9 \%$ & & 16, \\
\hline & East & $23.0 \%$ & $34.9 \%$ & $4.0 \%$ & $11.6 \%$ & $73.0 \%$ & $53.5 \%$ & $8.3 \%$ & $35.7 \%$ & 158,455 & 3,307,143 \\
\hline \multirow[t]{3}{*}{2007} & Germany & $36.1 \%$ & $49.6 \%$ & $2.3 \%$ & $7.1 \%$ & $61.6 \%$ & $43.3 \%$ & $8.2 \%$ & $41.8 \%$ & 845,867 & $20,877,923$ \\
\hline & West & $39.5 \%$ & $52.6 \%$ & $1.8 \%$ & $6.4 \%$ & $58.8 \%$ & $41.0 \%$ & $8.3 \%$ & $43.4 \%$ & 687,572 & $17,544,698$ \\
\hline & East & $21.6 \%$ & $33.8 \%$ & $4.4 \%$ & $11.2 \%$ & $74.0 \%$ & $55.0 \%$ & $7.9 \%$ & $33.7 \%$ & 158,294 & 3,333,224 \\
\hline \multirow[t]{3}{*}{2008} & Germany & $35.4 \%$ & $48.1 \%$ & $2.7 \%$ & $7.7 \%$ & $61.9 \%$ & $44.2 \%$ & $8.1 \%$ & $41.7 \%$ & 890,681 & $21,860,557$ \\
\hline & West & $38.5 \%$ & $51.0 \%$ & $2.2 \%$ & $7.1 \%$ & $59.3 \%$ & $41.9 \%$ & $8.2 \%$ & $43.3 \%$ & 716,913 & $18,248,031$ \\
\hline & East & $22.7 \%$ & $33.5 \%$ & $4.4 \%$ & $10.9 \%$ & $72.9 \%$ & $55.6 \%$ & $7.6 \%$ & $33.8 \%$ & 173,768 & $3,612,526$ \\
\hline
\end{tabular}

Note: I denotes the proportion of establishments; II denotes the proportion of employees. 


\section{APPENDIX TABLE 2}

Collective Bargaining and Works Council Coverage for Germany and by Broad Region, 2000-2008, Permanent Stayers, Weighted Data

\begin{tabular}{|c|c|c|c|c|c|c|c|c|c|c|c|}
\hline \multirow[b]{3}{*}{ Year } & \multirow[b]{3}{*}{ Region } & \multicolumn{6}{|c|}{ Collective Agreement Status } & \multirow{2}{*}{\multicolumn{2}{|c|}{$\begin{array}{l}\text { Works } \\
\text { Council }\end{array}$}} & \multirow{2}{*}{\multicolumn{2}{|c|}{ Totals }} \\
\hline & & \multicolumn{2}{|c|}{$\begin{array}{c}\text { Sectoral } \\
\text { Agreement }\end{array}$} & \multicolumn{2}{|c|}{$\begin{array}{c}\text { Firm-Level } \\
\text { Agreement }\end{array}$} & \multicolumn{2}{|c|}{$\begin{array}{c}\text { No } \\
\text { Agreement }\end{array}$} & & & & \\
\hline & & $\mathrm{I}$ & II & $\mathrm{I}$ & II & $\mathrm{I}$ & II & $\mathrm{I}$ & II & $\mathrm{I}$ & II \\
\hline \multirow[t]{3}{*}{2000} & Germany & $50.1 \%$ & $60.0 \%$ & $2.0 \%$ & $5.0 \%$ & $47.9 \%$ & $35.0 \%$ & $10.6 \%$ & $41.5 \%$ & 171,876 & $4,028,286$ \\
\hline & West & $57.3 \%$ & $65.9 \%$ & $1.2 \%$ & $3.8 \%$ & $41.5 \%$ & $30.3 \%$ & $10.3 \%$ & $42.6 \%$ & 132,017 & $3,137,725$ \\
\hline & East & $26.2 \%$ & $39.1 \%$ & $4.6 \%$ & $9.1 \%$ & $69.2 \%$ & $51.8 \%$ & & $37.8 \%$ & 39,859 & \\
\hline \multirow[t]{3}{*}{2001} & Germany & $49.4 \%$ & $59.0 \%$ & $3.7 \%$ & $6.5 \%$ & $46.8 \%$ & $34.4 \%$ & $11.1 \%$ & $43.6 \%$ & 151,853 & \\
\hline & West & $55.9 \%$ & $64.7 \%$ & $3.1 \%$ & $5.0 \%$ & $41.0 \%$ & & & & & \\
\hline & East & $29.5 \%$ & $39.2 \%$ & $5.7 \%$ & $11.8 \%$ & $64.8 \%$ & $49.0 \%$ & $12.4 \%$ & $39.8 \%$ & 37,118 & 859, \\
\hline \multirow[t]{3}{*}{2002} & Germany & $47.2 \%$ & $59.4 \%$ & $2.4 \%$ & $6.6 \%$ & $50.5 \%$ & $34.1 \%$ & $8.6 \%$ & $42.5 \%$ & & \\
\hline & West & $55.3 \%$ & $66.0 \%$ & $1.4 \%$ & $5.0 \%$ & & & & & & \\
\hline & East & $25.1 \%$ & $37.6 \%$ & $5.0 \%$ & $11.5 \%$ & $69.9 \%$ & $50.9 \%$ & $8.1 \%$ & $34.9 \%$ & 42,341 & 90 \\
\hline \multirow[t]{3}{*}{2003} & Germany & $48.7 \%$ & $59.7 \%$ & $1.8 \%$ & $7.2 \%$ & $49.4 \%$ & $33.1 \%$ & $9.2 \%$ & $45.6 \%$ & 155,478 & $4,042,618$ \\
\hline & West & $56.3 \%$ & $65.3 \%$ & $1.3 \%$ & $6.2 \%$ & $42.5 \%$ & $28.6 \%$ & $9.7 \%$ & $47.8 \%$ & 424 & \\
\hline & East & & $40.1 \%$ & $3.5 \%$ & & & & & & & \\
\hline \multirow[t]{3}{*}{2004} & Germany & $45.7 \%$ & $56.4 \%$ & $3.0 \%$ & $7.7 \%$ & $51.3 \%$ & $35.9 \%$ & $9.1 \%$ & $43.8 \%$ & 148,167 & 3,682 \\
\hline & West & $52.9 \%$ & $62.1 \%$ & $2.9 \%$ & $6.9 \%$ & $44.2 \%$ & $31.0 \%$ & $9.2 \%$ & $45.4 \%$ & 110,602 & $2,875,064$ \\
\hline & East & $24.3 \%$ & $36.1 \%$ & $3.5 \%$ & $10.5 \%$ & $72.2 \%$ & & $8.6 \%$ & $38.3 \%$ & 37,565 & \\
\hline \multirow[t]{3}{*}{2005} & Germany & $45.5 \%$ & $55.9 \%$ & $3.0 \%$ & $6.7 \%$ & $51.5 \%$ & $37.4 \%$ & $8.7 \%$ & $41.9 \%$ & 150,288 & 3,60 \\
\hline & West & $50.7 \%$ & $60.1 \%$ & $2.5 \%$ & $5.7 \%$ & $46.8 \%$ & $34.3 \%$ & $9.0 \%$ & $43.0 \%$ & 11 & 2,8 \\
\hline & East & $29.1 \%$ & $40.3 \%$ & $4.4 \%$ & $10.6 \%$ & $66.5 \%$ & $49.1 \%$ & $7.9 \%$ & $37.7 \%$ & 35,824 & 770,458 \\
\hline \multirow[t]{3}{*}{2006} & Germany & $42.3 \%$ & $55.5 \%$ & $2.8 \%$ & $6.9 \%$ & $54.8 \%$ & & $1 \%$ & $44.4 \%$ & 148,835 & \\
\hline & West & $48.0 \%$ & $60.2 \%$ & $2.2 \%$ & $6.0 \%$ & $49.8 \%$ & $33.8 \%$ & $9.3 \%$ & $46.4 \%$ & 112,449 & \\
\hline & East & $25.0 \%$ & $37.6 \%$ & $4.6 \%$ & $10.3 \%$ & $70.4 \%$ & $52.2 \%$ & $8.3 \%$ & $36.7 \%$ & 36,385 & 766,492 \\
\hline \multirow[t]{3}{*}{2007} & Germany & $39.7 \%$ & $53.7 \%$ & $2.6 \%$ & $7.1 \%$ & $57.8 \%$ & $39.2 \%$ & $9.5 \%$ & $46.7 \%$ & 147,964 & $3,947,225$ \\
\hline & West & $44.5 \%$ & $57.6 \%$ & $1.7 \%$ & $6.5 \%$ & $53.8 \%$ & $36.0 \%$ & $10.1 \%$ & $49.3 \%$ & 112,206 & $3,170,173$ \\
\hline & East & $24.6 \%$ & $38.1 \%$ & $5.3 \%$ & $9.7 \%$ & $70.0 \%$ & $52.2 \%$ & $7.7 \%$ & $36.2 \%$ & 35,758 & 777,053 \\
\hline \multirow[t]{3}{*}{2008} & Germany & $40.1 \%$ & $52.8 \%$ & $2.4 \%$ & $7.4 \%$ & $57.6 \%$ & $39.8 \%$ & $9.7 \%$ & $48.0 \%$ & 151,394 & $4,045,311$ \\
\hline & West & $45.7 \%$ & $56.8 \%$ & $1.1 \%$ & $6.0 \%$ & $53.2 \%$ & $37.2 \%$ & $10.2 \%$ & $50.3 \%$ & 112,196 & $3,179,942$ \\
\hline & East & $23.9 \%$ & $38.1 \%$ & $6.0 \%$ & $12.6 \%$ & $70.1 \%$ & $49.4 \%$ & $8.4 \%$ & $39.7 \%$ & 39,198 & 865,369 \\
\hline
\end{tabular}

Note: I denotes the proportion of establishments; II denotes the proportion of employees. 


\section{APPENDIX TABLE 3}

Collective Bargaining and Works Council Coverage for Germany and by Broad Region, 2000-2008, NewlyFounded Establishments, Weighted Data

\begin{tabular}{|c|c|c|c|c|c|c|c|c|c|c|c|}
\hline \multirow[b]{3}{*}{ Year } & \multirow[b]{3}{*}{ Region } & \multicolumn{6}{|c|}{ Collective Agreement Status } & & & & \\
\hline & & \multicolumn{2}{|c|}{$\begin{array}{c}\text { Sectoral } \\
\text { Agreement }\end{array}$} & \multicolumn{2}{|c|}{$\begin{array}{c}\text { Firm-Level } \\
\text { Agreement }\end{array}$} & \multicolumn{2}{|c|}{$\begin{array}{c}\text { No } \\
\text { Agreement }\end{array}$} & \multicolumn{2}{|c|}{$\begin{array}{l}\text { Works } \\
\text { Council }\end{array}$} & \multicolumn{2}{|c|}{ Totals } \\
\hline & & $\mathrm{I}$ & II & $\mathrm{I}$ & II & $\mathrm{I}$ & II & $\mathrm{I}$ & II & $\mathrm{I}$ & II \\
\hline \multirow[t]{3}{*}{2000} & Germany & $33.0 \%$ & $41.8 \%$ & $2.2 \%$ & $5.6 \%$ & $64.8 \%$ & $52.6 \%$ & $6.1 \%$ & $38.1 \%$ & 51,767 & 922,628 \\
\hline & West & $38.6 \%$ & $43.4 \%$ & $2.3 \%$ & $6.2 \%$ & $59.1 \%$ & $50.4 \%$ & $6.2 \%$ & $40.7 \%$ & 39,502 & 742,246 \\
\hline & East & $15.0 \%$ & $35.6 \%$ & $2.0 \%$ & $3.0 \%$ & $83.0 \%$ & $61.4 \%$ & $5.8 \%$ & $27.5 \%$ & 12,265 & 180,382 \\
\hline \multirow[t]{3}{*}{2001} & Germany & $30.0 \%$ & $43.8 \%$ & $5.0 \%$ & $10.2 \%$ & $65.0 \%$ & $46.0 \%$ & $10.5 \%$ & $38.8 \%$ & 47,494 & 805,435 \\
\hline & West & $38.1 \%$ & $50.6 \%$ & $6.1 \%$ & $10.4 \%$ & $55.8 \%$ & $39.0 \%$ & $11.9 \%$ & $41.4 \%$ & 35,637 & 661,509 \\
\hline & East & $5.7 \%$ & $12.9 \%$ & $1.8 \%$ & $9.0 \%$ & $92.5 \%$ & $78.1 \%$ & $6.5 \%$ & $26.9 \%$ & 11,857 & 143,926 \\
\hline \multirow[t]{3}{*}{2002} & Germany & $30.9 \%$ & $46.3 \%$ & $2.0 \%$ & $7.1 \%$ & $67.2 \%$ & $46.6 \%$ & $6.6 \%$ & $37.8 \%$ & 50,909 & 842,489 \\
\hline & West & $33.1 \%$ & $49.4 \%$ & $1.2 \%$ & $5.5 \%$ & $65.7 \%$ & $45.1 \%$ & $5.9 \%$ & $38.0 \%$ & 43,083 & 706,103 \\
\hline & East & $18.8 \%$ & $30.3 \%$ & $6.2 \%$ & $15.3 \%$ & $75.0 \%$ & $54.4 \%$ & $10.3 \%$ & $37.0 \%$ & 7,826 & 136,386 \\
\hline \multirow[t]{3}{*}{2003} & Germany & $35.1 \%$ & $31.6 \%$ & $1.9 \%$ & $9.7 \%$ & $63.0 \%$ & & $5.6 \%$ & & 6,661 & \\
\hline & West & $54.8 \%$ & $38.9 \%$ & $3.0 \%$ & $12.5 \%$ & $42.2 \%$ & $48.5 \%$ & $6.3 \%$ & $30.7 \%$ & 3,790 & 64,771 \\
\hline & East & $9.2 \%$ & $18.2 \%$ & $0.4 \%$ & $4.5 \%$ & $90.4 \%$ & $77.3 \%$ & $4.6 \%$ & $24.5 \%$ & 2,871 & 35,361 \\
\hline \multirow[t]{3}{*}{2004} & Germany & $27.7 \%$ & $39.0 \%$ & $3.6 \%$ & $9.9 \%$ & $68.7 \%$ & $51.1 \%$ & $7.2 \%$ & $36.5 \%$ & 56,895 & 981,487 \\
\hline & West & $31.2 \%$ & $42.0 \%$ & $4.2 \%$ & $10.8 \%$ & $64.6 \%$ & & $8.7 \%$ & $39.1 \%$ & 41,378 & \\
\hline & East & $18.5 \%$ & $29.5 \%$ & $1.8 \%$ & $6.8 \%$ & $79.7 \%$ & $63.7 \%$ & $2.2 \%$ & $8.2 \%$ & 15,517 & 232,298 \\
\hline \multirow[t]{3}{*}{2005} & Germany & $37.0 \%$ & $42.6 \%$ & $1.2 \%$ & $4.5 \%$ & $61.8 \%$ & $52.9 \%$ & $6.5 \%$ & $23.0 \%$ & 60,896 & 952,386 \\
\hline & West & $38.4 \%$ & $43.0 \%$ & $0.7 \%$ & $3.7 \%$ & $61.0 \%$ & $53.3 \%$ & $7.2 \%$ & $25.6 \%$ & 50,308 & 783,083 \\
\hline & East & $33.3 \%$ & $40.9 \%$ & $3.7 \%$ & $7.9 \%$ & $65.6 \%$ & $51.2 \%$ & $3.2 \%$ & $11.3 \%$ & 10,589 & 169,303 \\
\hline \multirow[t]{3}{*}{2006} & Germany & $30.8 \%$ & $40.4 \%$ & $2.8 \%$ & $5.9 \%$ & $66.4 \%$ & $53.7 \%$ & $7.4 \%$ & $24.2 \%$ & 64,603 & $1,003,675$ \\
\hline & West & $33.2 \%$ & $44.0 \%$ & $2.6 \%$ & $4.9 \%$ & $64.2 \%$ & $51.1 \%$ & $8.4 \%$ & $26.4 \%$ & 50,235 & 802,905 \\
\hline & East & $22.5 \%$ & $26.1 \%$ & $3.6 \%$ & $9.6 \%$ & $74.0 \%$ & $64.3 \%$ & $3.6 \%$ & $15.4 \%$ & 14,369 & 200,770 \\
\hline \multirow[t]{3}{*}{2007} & Germany & $29.6 \%$ & $39.0 \%$ & $3.7 \%$ & $4.3 \%$ & $66.8 \%$ & $56.7 \%$ & $4.7 \%$ & $24.7 \%$ & 68,967 & $1,198,914$ \\
\hline & West & $31.2 \%$ & $41.2 \%$ & $4.2 \%$ & $3.6 \%$ & $64.6 \%$ & $55.2 \%$ & $4.5 \%$ & $25.9 \%$ & 55,260 & 982,876 \\
\hline & East & $22.9 \%$ & $29.0 \%$ & $1.5 \%$ & $7.2 \%$ & $75.6 \%$ & $63.8 \%$ & $5.5 \%$ & $19.1 \%$ & 13,708 & 216,038 \\
\hline \multirow[t]{3}{*}{2008} & Germany & $32.5 \%$ & $38.4 \%$ & $3.3 \%$ & $7.3 \%$ & $64.2 \%$ & $54.3 \%$ & $5.2 \%$ & $25.6 \%$ & 74,172 & $1,208,916$ \\
\hline & West & $33.9 \%$ & $39.1 \%$ & $3.4 \%$ & $7.4 \%$ & $62.7 \%$ & $53.5 \%$ & $5.2 \%$ & $26.4 \%$ & 60,048 & $1,012,792$ \\
\hline & East & $26.4 \%$ & $34.6 \%$ & $2.9 \%$ & $6.7 \%$ & $70.7 \%$ & $58.7 \%$ & $5.0 \%$ & $21.4 \%$ & 14,124 & 196,124 \\
\hline
\end{tabular}

Notes: Newly-founded establishments correspond to the sum of groups 1, 5, 6, and 7 in Table 1. I denotes the proportion of establishments; II denotes the proportion of employees. 


\section{APPENDIX TABLE 4}

Collective Bargaining and Works Council Coverage for Germany and by Broad Regions, 2000-2008, Closing/Failing Establishments, Weighted Data

\begin{tabular}{|c|c|c|c|c|c|c|c|c|c|c|c|}
\hline \multirow[b]{3}{*}{ Year } & \multirow[b]{3}{*}{ Region } & \multicolumn{6}{|c|}{ Collective Agreement Status } & \multirow{2}{*}{\multicolumn{2}{|c|}{$\begin{array}{l}\text { Works } \\
\text { Council }\end{array}$}} & \multirow{2}{*}{\multicolumn{2}{|c|}{ Totals }} \\
\hline & & \multicolumn{2}{|c|}{$\begin{array}{c}\text { Sectoral } \\
\text { Agreement }\end{array}$} & \multicolumn{2}{|c|}{$\begin{array}{c}\text { Firm-Level } \\
\text { Agreement }\end{array}$} & \multicolumn{2}{|c|}{$\begin{array}{c}\text { No } \\
\text { Agreement }\end{array}$} & & & & \\
\hline & & $\mathrm{I}$ & II & I & II & $\mathrm{I}$ & II & $\mathrm{I}$ & II & I & II \\
\hline \multirow[t]{3}{*}{2000} & Germany & $31.3 \%$ & $45.4 \%$ & $7.7 \%$ & $8.8 \%$ & $61.0 \%$ & $45.8 \%$ & $13.3 \%$ & $30.8 \%$ & 27,253 & 480,266 \\
\hline & West & $35.9 \%$ & $51.9 \%$ & $6.8 \%$ & $6.2 \%$ & $57.4 \%$ & $41.9 \%$ & $13.9 \%$ & $30.3 \%$ & 20,131 & 343,376 \\
\hline & East & $18.4 \%$ & $29.0 \%$ & $10.3 \%$ & $15.4 \%$ & $71.3 \%$ & $55.7 \%$ & $11.7 \%$ & $32.1 \%$ & 7,122 & 136,890 \\
\hline \multirow[t]{3}{*}{2001} & Germany & $33.6 \%$ & $46.0 \%$ & $2.7 \%$ & $7.2 \%$ & $63.7 \%$ & $46.7 \%$ & $14.9 \%$ & $41.7 \%$ & 30,049 & 528,762 \\
\hline & West & $35.2 \%$ & $48.4 \%$ & $1.4 \%$ & $6.2 \%$ & $63.4 \%$ & $45.4 \%$ & $13.8 \%$ & $44.2 \%$ & 21,345 & 409,982 \\
\hline & East & $29.7 \%$ & $37.8 \%$ & $5.9 \%$ & $10.8 \%$ & $64.3 \%$ & $51.4 \%$ & $17.5 \%$ & $33.0 \%$ & 8,703 & 118,780 \\
\hline \multirow[t]{3}{*}{2002} & Germany & $48.7 \%$ & $53.7 \%$ & $2.2 \%$ & $6.9 \%$ & $49.1 \%$ & $39.4 \%$ & $14.0 \%$ & $39.3 \%$ & 38,510 & 618,349 \\
\hline & West & $53.9 \%$ & $60.9 \%$ & $0.9 \%$ & $3.1 \%$ & $45.2 \%$ & $36.1 \%$ & $13.7 \%$ & $38.3 \%$ & 29,910 & 478,306 \\
\hline & East & $30.6 \%$ & $29.4 \%$ & $6.8 \%$ & $19.9 \%$ & $62.6 \%$ & $50.7 \%$ & $15.2 \%$ & $42.9 \%$ & 8,601 & 140,043 \\
\hline \multirow[t]{3}{*}{2003} & Germany & $51.0 \%$ & $57.7 \%$ & $1.5 \%$ & $5.9 \%$ & $47.5 \%$ & $36.4 \%$ & $14.2 \%$ & $41.9 \%$ & 28,758 & 494,991 \\
\hline & West & $55.8 \%$ & $62.6 \%$ & $1.1 \%$ & $5.9 \%$ & $43.1 \%$ & $31.6 \%$ & $13.9 \%$ & $42.9 \%$ & 23,185 & 407,077 \\
\hline & East & $31.2 \%$ & $35.3 \%$ & $2.9 \%$ & $6.3 \%$ & $65.9 \%$ & & $15.5 \%$ & & 5,574 & \\
\hline \multirow[t]{3}{*}{2004} & Germany & $51.0 \%$ & $52.7 \%$ & $1.0 \%$ & $11.0 \%$ & $48.1 \%$ & $36.4 \%$ & $8.9 \%$ & $37.6 \%$ & 29,903 & 512,595 \\
\hline & West & $54.3 \%$ & $57.3 \%$ & $0.7 \%$ & $7.7 \%$ & $45.1 \%$ & $35.0 \%$ & $8.5 \%$ & $37.1 \%$ & 24,748 & 419,193 \\
\hline & East & $35.1 \%$ & $31.9 \%$ & $2.6 \%$ & $25.5 \%$ & $62.4 \%$ & $42.6 \%$ & $10.6 \%$ & $40.1 \%$ & 5,155 & 93,402 \\
\hline \multirow[t]{3}{*}{2005} & Germany & $38.9 \%$ & $42.4 \%$ & $6.1 \%$ & $12.8 \%$ & $55.1 \%$ & $44.8 \%$ & $11.7 \%$ & $33.7 \%$ & 31,658 & 472,637 \\
\hline & West & $42.9 \%$ & $45.6 \%$ & $6.8 \%$ & $13.8 \%$ & $50.3 \%$ & $40.7 \%$ & $12.4 \%$ & $34.8 \%$ & 26,819 & 393,365 \\
\hline & East & $16.6 \%$ & $26.4 \%$ & $1.9 \%$ & $8.0 \%$ & $81.5 \%$ & $65.6 \%$ & $7.5 \%$ & $28.2 \%$ & 4,839 & 79,272 \\
\hline \multirow[t]{3}{*}{2006} & Germany & $41.6 \%$ & $47.9 \%$ & $3.6 \%$ & $5.6 \%$ & $54.8 \%$ & $46.5 \%$ & $11.9 \%$ & $36.8 \%$ & 26,590 & 427,300 \\
\hline & West & $44.0 \%$ & $49.6 \%$ & $2.9 \%$ & $4.5 \%$ & $53.0 \%$ & $45.8 \%$ & $13.0 \%$ & $37.5 \%$ & 22,356 & 348,115 \\
\hline & East & $28.6 \%$ & $40.3 \%$ & $7.4 \%$ & $10.4 \%$ & $64.0 \%$ & $49.3 \%$ & $6.2 \%$ & $34.1 \%$ & 4,234 & 79,185 \\
\hline \multirow[t]{3}{*}{2007} & Germany & $32.9 \%$ & $38.6 \%$ & $0.9 \%$ & $6.6 \%$ & $66.1 \%$ & $54.8 \%$ & $9.2 \%$ & $29.8 \%$ & 24,278 & 429,057 \\
\hline & West & $37.4 \%$ & $40.2 \%$ & $0.6 \%$ & $7.0 \%$ & $62.0 \%$ & $52.9 \%$ & $10.4 \%$ & $30.7 \%$ & 19,549 & 353,197 \\
\hline & East & $14.6 \%$ & $31.2 \%$ & $2.2 \%$ & $5.0 \%$ & $83.3 \%$ & $63.8 \%$ & $4.2 \%$ & $25.6 \%$ & 4,729 & 75,860 \\
\hline \multirow[t]{3}{*}{2008} & Germany & $23.5 \%$ & $39.2 \%$ & $2.3 \%$ & $6.9 \%$ & $74.2 \%$ & $53.8 \%$ & $7.8 \%$ & $28.4 \%$ & 28,381 & 405,561 \\
\hline & West & $24.5 \%$ & $39.4 \%$ & $2.4 \%$ & $6.8 \%$ & $73.1 \%$ & $53.7 \%$ & $7.9 \%$ & $28.1 \%$ & 24,236 & 337,808 \\
\hline & East & $17.4 \%$ & $38.3 \%$ & $1.9 \%$ & $7.4 \%$ & $80.7 \%$ & $54.3 \%$ & $6.9 \%$ & $29.7 \%$ & 4,144 & 67,753 \\
\hline
\end{tabular}

Note: Closing/failing establishments correspond to the sum of groups 6, 9, and 12 in Table 1 . I denotes the proportion of establishments; II denotes the proportion of employees. 
FIGURE 1

Collective Bargaining and Works Council Coverage by Establishment for Germany and by Broad Region, 20002008 (establishments with at least 5 employees, cross-section weighted data)

(a) Germany

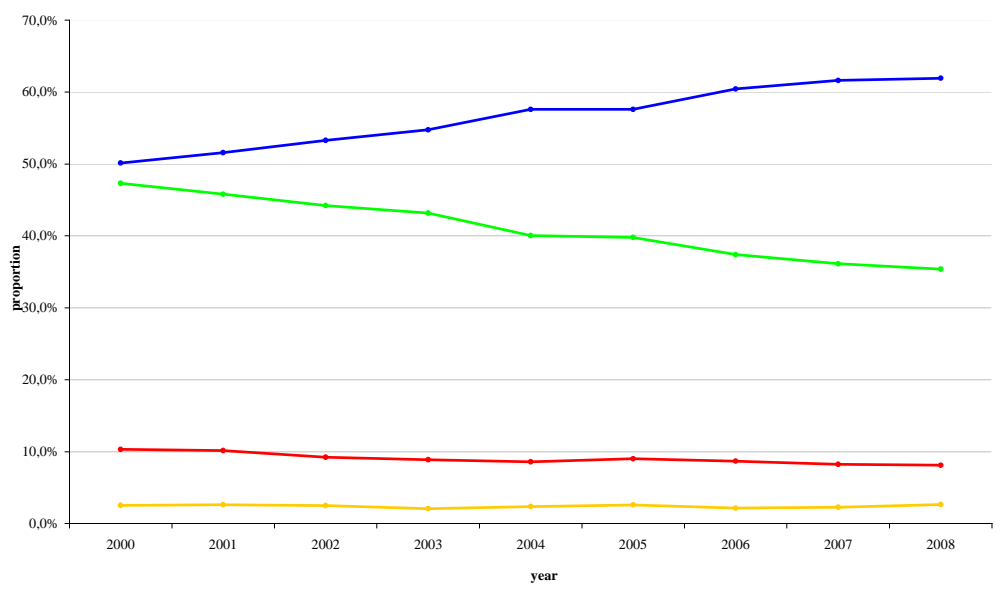

(b) Western Germany

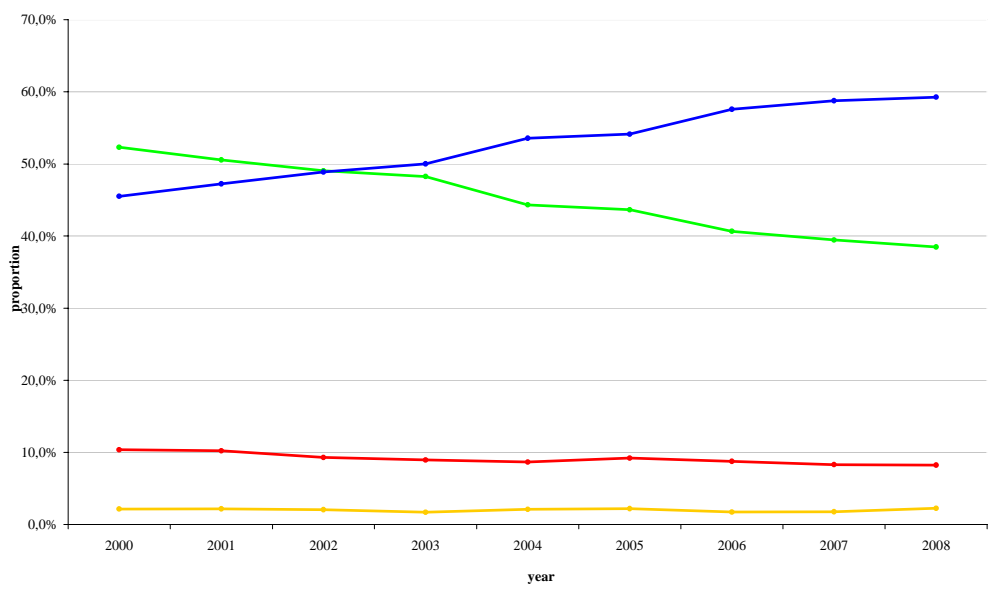

(c) Eastern Germany

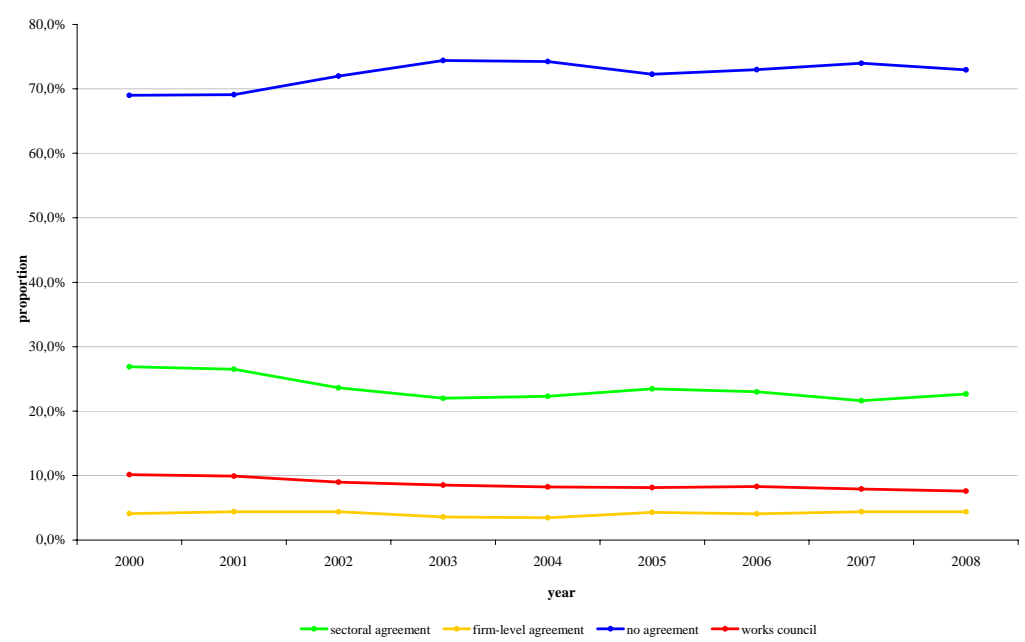


FIGURE 2

Collective Bargaining and Works Council Coverage by Employment for Germany and by Broad Region, 20002008 (establishments with at least 5 employees, cross-section weighted data)

(a) Germany

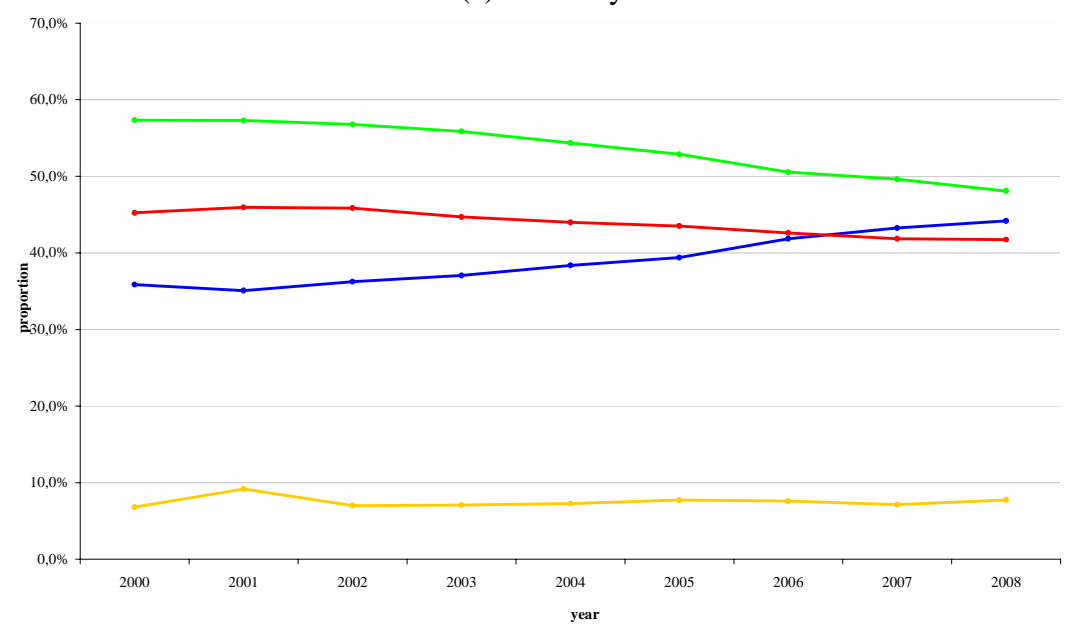

(b) Western Germany

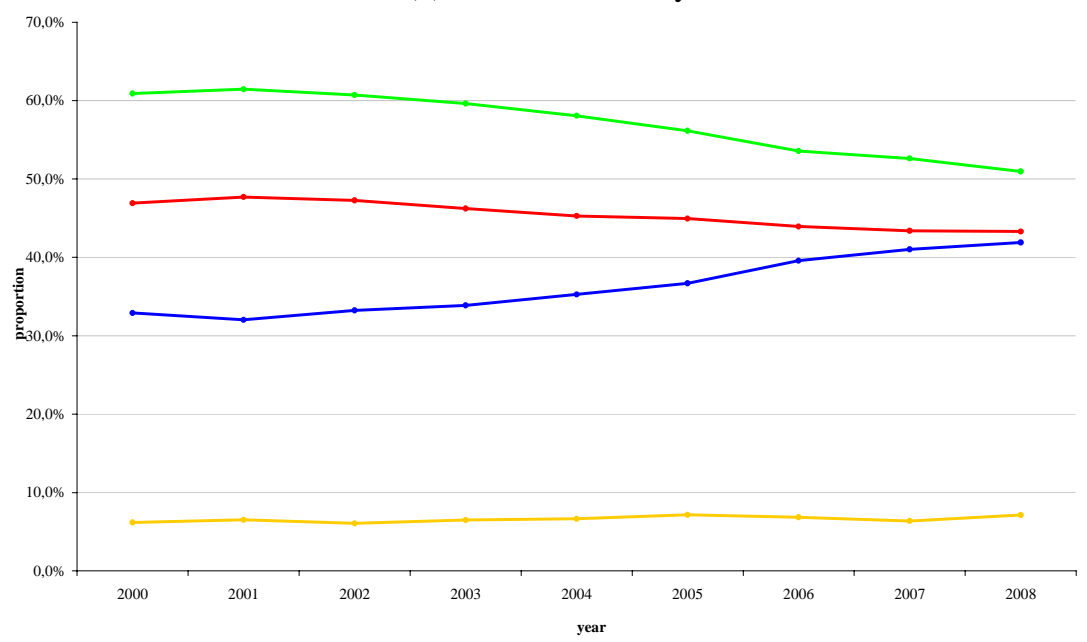

(c) Eastern Germany

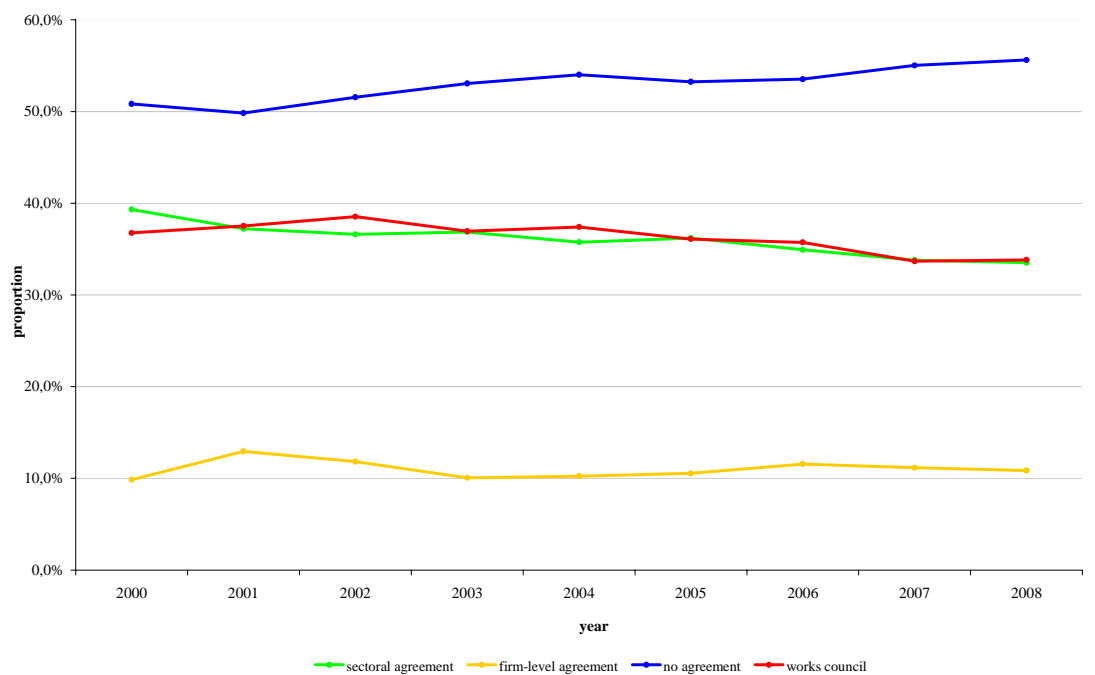


FIGURE 3

Collective Bargaining and Works Council Coverage by Establishment for Germany and by Broad Region, Permanent Stayers, 2000-2008 (establishments with at least 5 employees, cross-section weighted data)

(a) Germany

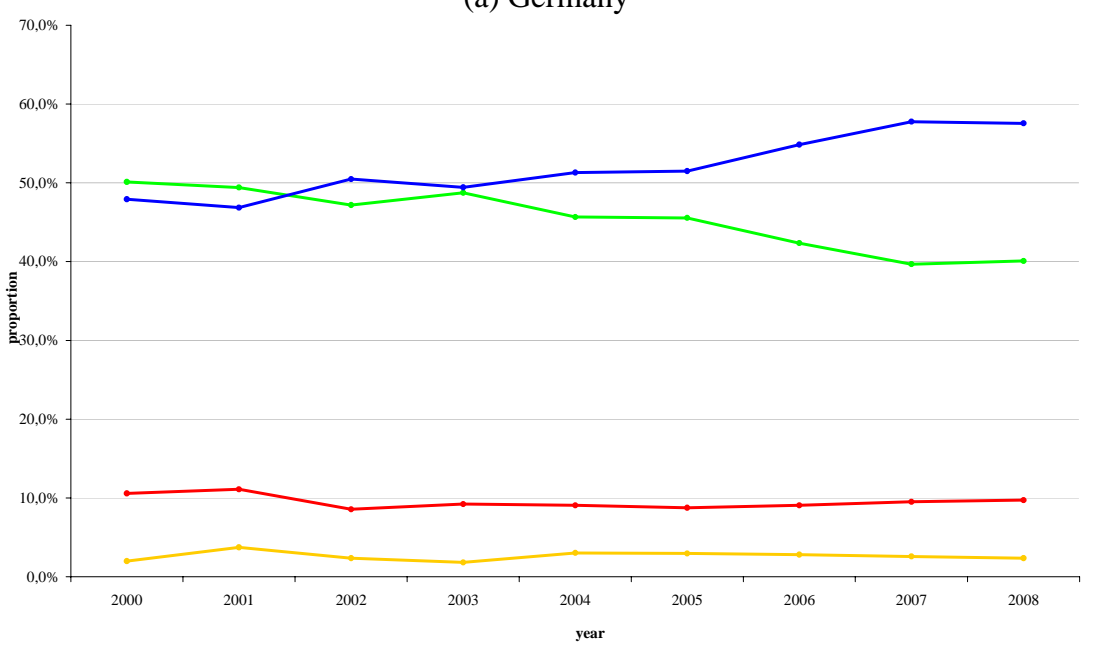

(b) Western Germany

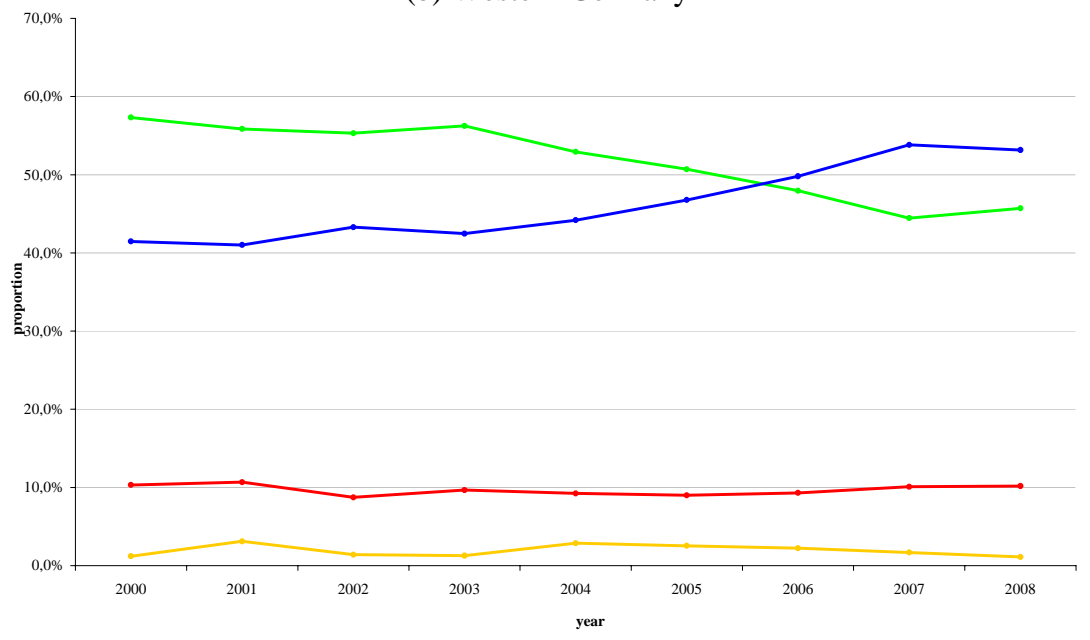

(c) Eastern Germany

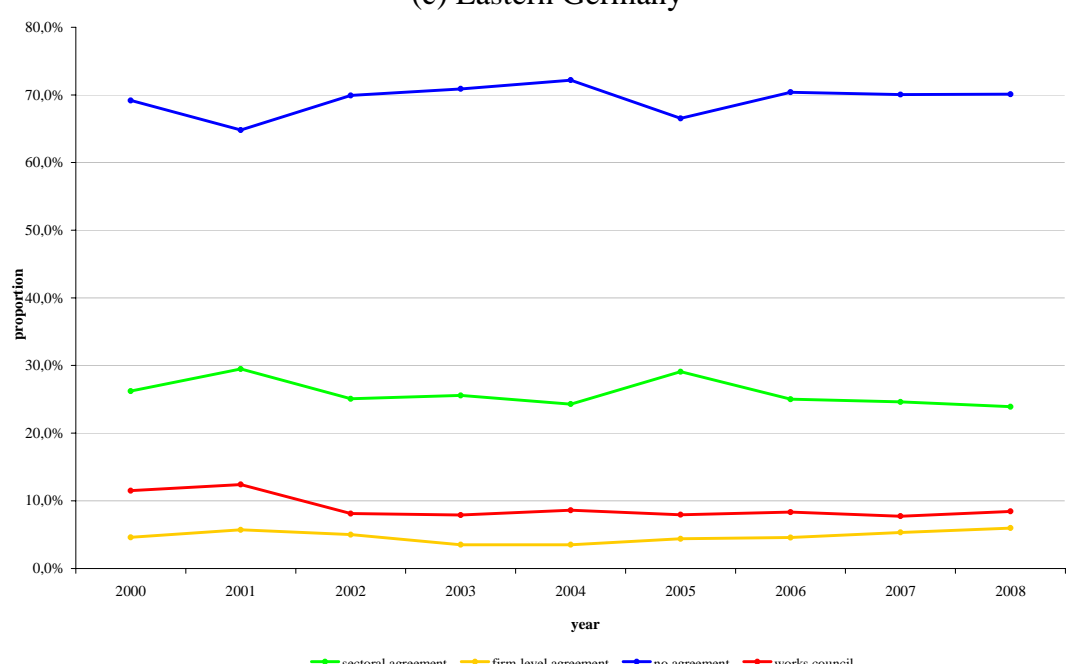


FIGURE 4

Collective Bargaining and Works Council Coverage by Employment for Germany and by Broad Region, Permanent Stayers, 2000-2008 (establishments with at least 5 employees, cross-section weighted data)

\section{(a) Germany}

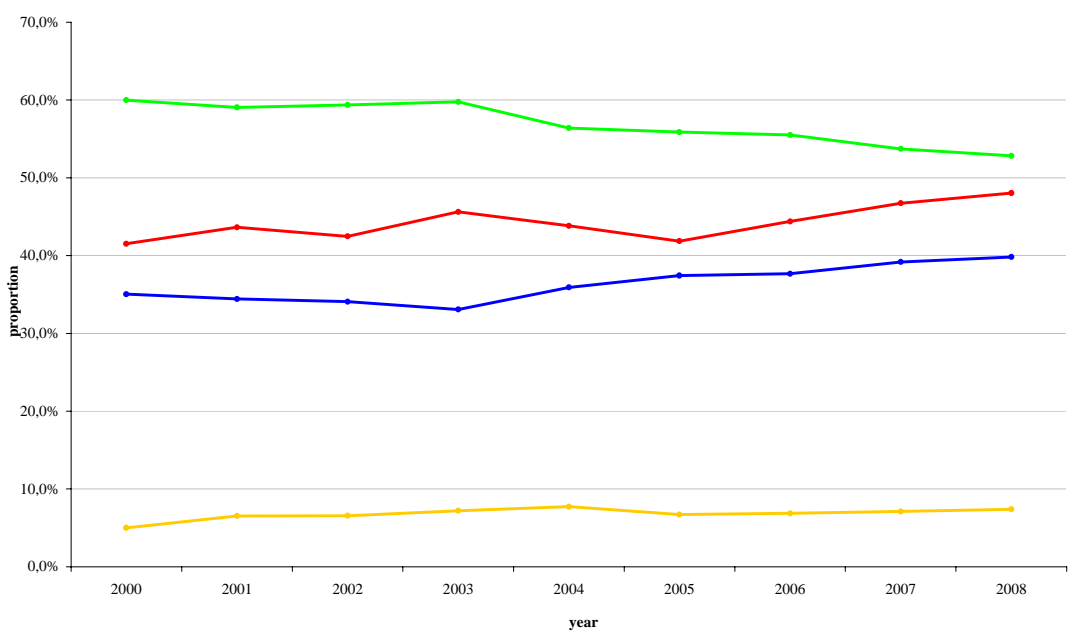

(b) Western Germany

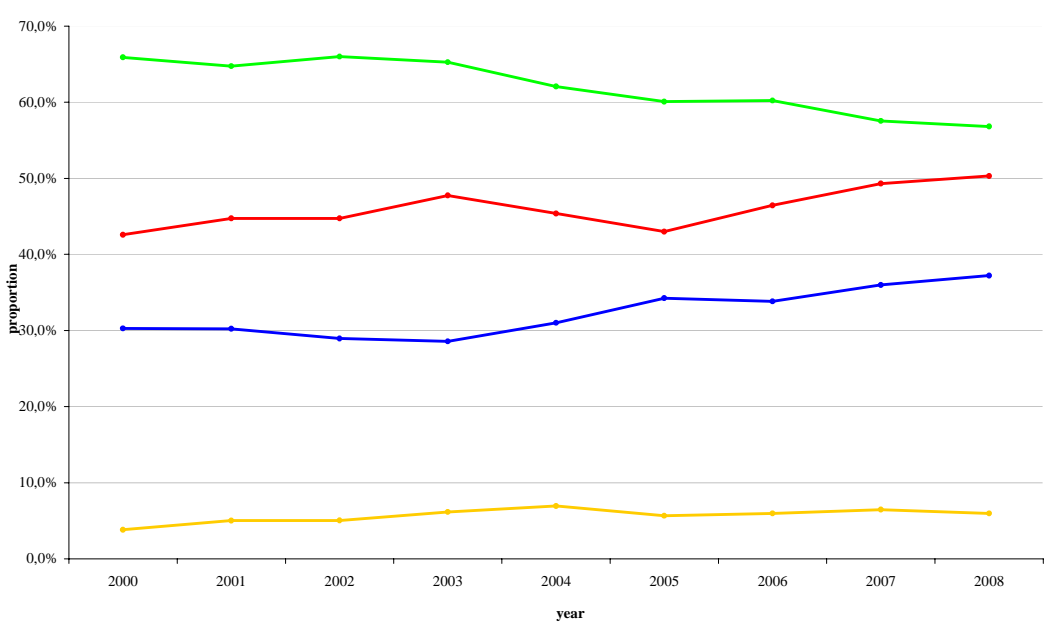

(c) Eastern Germany

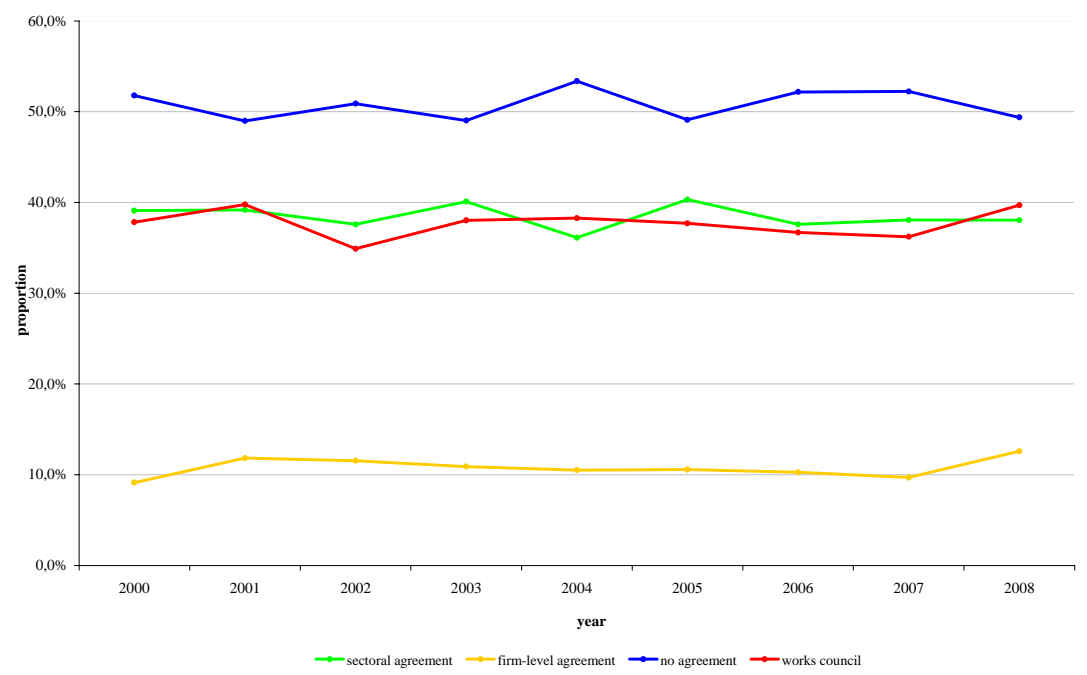


FIGURE 5

Collective Bargaining and Works Council Coverage by Establishment and Employment in Newly-Founded Establishments (i.e. Births), Germany, 2000-2008 (establishments with at least 5 employees, cross-section weighted data)

(a) Coverage by Establishment

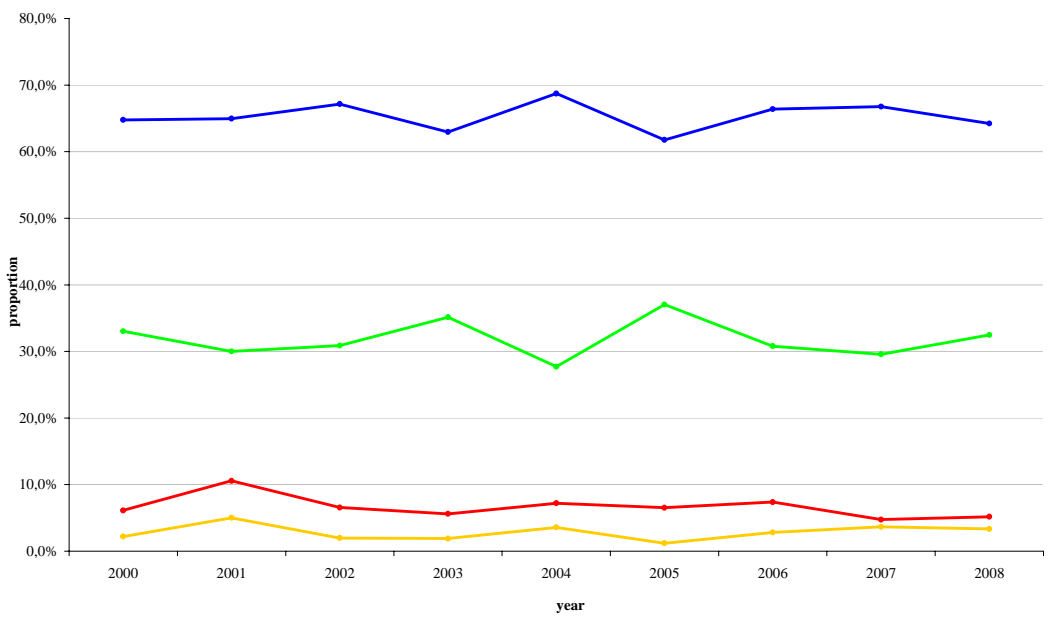

(b) Coverage by Employment

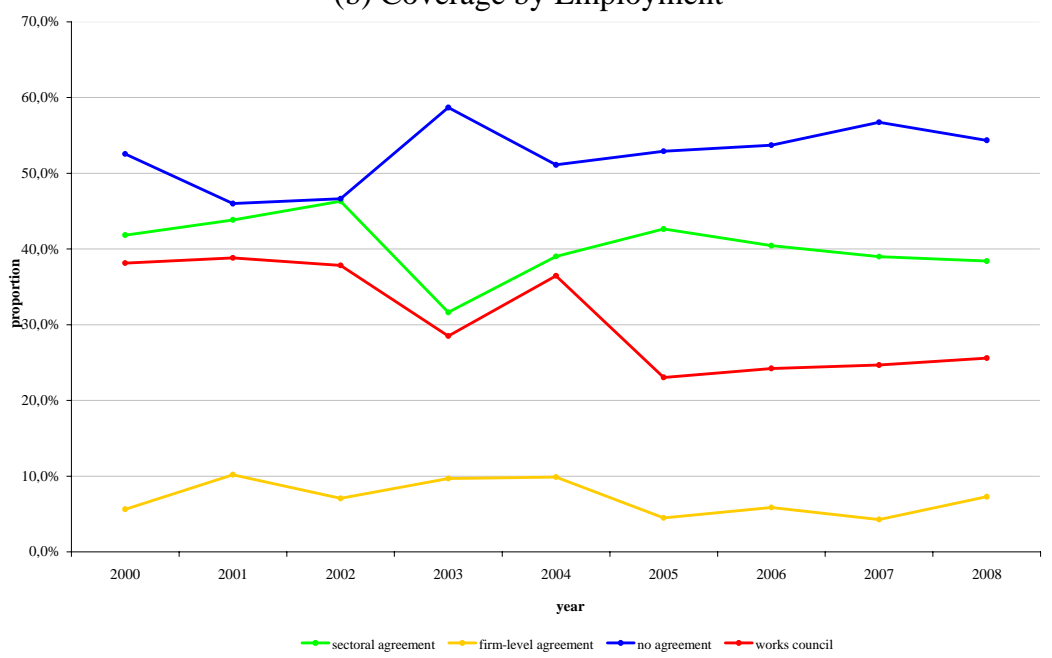


FIGURE 6

Collective Bargaining and Works Council Coverage by Establishment and Employment Among Closing Establishments (i.e. Deaths), Germany, 2000-2008 (establishments with at least 5 employees, cross-section weighted data)

(a) Coverage by Establishment

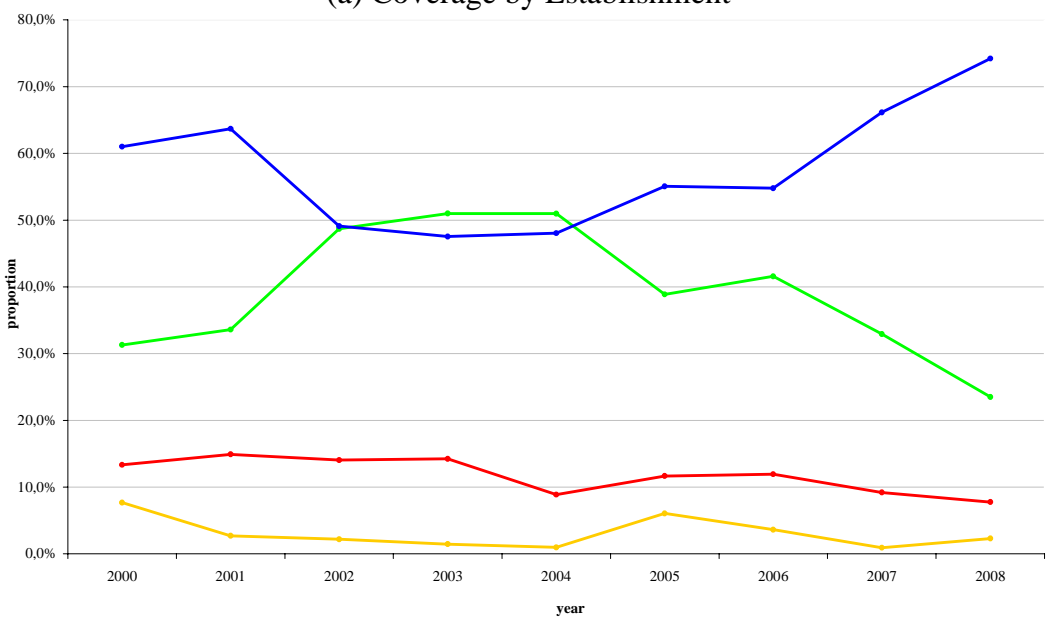

(b) Coverage by Employment

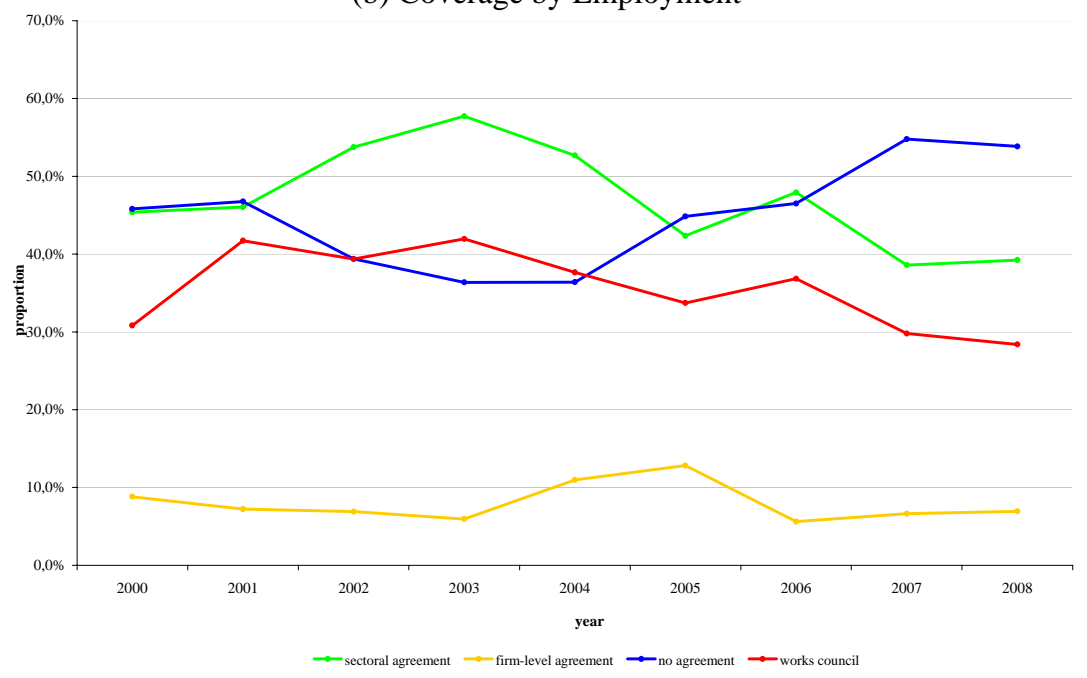

